\title{
DESENVOLVIMENTO DO ÁCARO PLANO, Brevipalpus phoenicis, (GEIJISKES, 1939) E OCORRÊNCIA DA MANCHA ANULAR EM FUNÇÃO DE ALGUNS NUTRIENTES NO CAFEEIRO, Coffea arabica L.
}

\author{
REYMAR COUTINHO DE ANDRADE \\ Engenheiro Agrônomo
}

Orientador: Prof. Dr. OCTÁVIO NAKANO

\begin{abstract}
Dissertação apresentada à Escola Superior de Agricultura "Luiz de Queiroz", Universidade de São Paulo, para obtenção do título de Mestre em Ciência, Área de Concentração: Entomologia.
\end{abstract}

\author{
PIRACICABA \\ Estado de São Paulo- Brasil \\ Julho - 2001
}




\section{ERRATA}

$\mathrm{Na}$ falha de impressão no final da página $X$, terceira linha de baixo para cima, onde se - lê: ...bem nutridas e principalm em enxofre, ... Leia-se: ...bem nutridas e principalmente ricas em enxofre, $\ldots$

A citação no primeiro parágrafo do item 2.4 página 6, onde cita-se (Pazzini e Parra, 1991), Leia-se: (Panizzi e Parra,1991) como referência dos autores.

O preenchimento da elipse das figuras 2,3 e 4 nas páginas 20 e 21, ao invés de cinza, entenda-se amarelo.

Nos quadros 1 e 2, as ruas que sofreram a aplicação de enxofre foram as ruas $\mathrm{A}$ e $\mathrm{C}$. 
Dados Internacionais de Catalogação na Publicaçāo (CIP)

DIVISĀO DE BIBLIOTECA E DOCUMENTAÇĀO - Campus "Luiz de QueirOz"/USP

Andrade, Reymar Coutinho de

Desenvolvimento do ácaro plano, Brevipalpus phoenicis, (Geijiskes, 1939) e

ocorrência da mancha anular em função de alguns nutrientes no cafeeiro, Coffea arabica

L. / Reymar Coutinho de Andrade. - Piracicaba, 2001.

$58 \mathrm{p}$.

Dissertação (mestrado) - Escola Superior de Agricultura Luiz de Queiroz, 2001.

Bibliografia.

1. Acaricida 2. Ácaro-vetor-de-doença 3. Café 4. Enxofre 5. Mancha-anular-docafeeiro 6. Nutriente 7. Zinco I. Título

CDD 633.73

Permitida a cópia total ou parcial deste documento, desde que citada a fonte $-\mathbf{O}$ autor" 
Aos meus pais, Reynaldo e Marina, que com carinho e dedicação, sempre me apoiaram em todas as etapas de minha vida.

A minha esposa Giovana, e filhos, Raissa e Renan, que com amor acompanharam e compreenderam os passos desta caminhada.

\section{DEDICO}

A professora, Maria Helena, que com dedicação me apoiou nesta jornada 


\section{AGRADECIMENTOS}

A Deus por estar sempre ao meu lado, iluminando meu caminho.

Ao Prof. Octávio Nakano, pelos ensinamentos e amizade construída ao longo do curso, sempre mostrando o melhor caminho para a pesquisa científica.

Ao Técnico Agricola Flávio Ramalho Luz, por sua amizade e colaboração nos ensaios de campo em Araguari, que muito contribuiu nos levantamentos realizados neste município.

Ao Sr. Nivaldo S. Ribeiro, que permitiu a realização dos ensaios na Fazenda Santa Cecília, e seu gerente "Maurinho" sempre pronto a ajudar na condução perfeita dos ensaios.

Ao Eng Agr. Sérgio de Salvo, pelas oportunidades e confiança conferida no início do curso.

A todos os professores do curso de pós-graduação que muito contribuíram para minha formação profissional e pessoal, em especial aos professores Sérgio Batista Alves e Evôneo Berti Filho, pela correção do summary, a Gilberto Casadei de Baptista, José Djair Vendramim e Luís Carlos Marchini, pelo relacionamento, conselhos e orientações. 
À Fundação de Amparo à Pesquisa do Estado de São Paulo FAPESP (Processo: 98/02936-1), pela concessão da bolsa de estudos para execução deste trabalho.

A Sra. Angela e Amália do escritório regional da FAPESP, que tanto ajudaram e esclareceram os termos dessa concessão.

A todos os amigos do curso de pós-graduação, pela amizade e auxilio nas diversas atividades desenvolvidas; a Ranyse pelo apoio no decorrer do curso, especialmente no início, a Vanderlei (Itamar) e Eduardo, pelo companheirismo e ajuda, superando sempre as dificuldades, dúvidas acadêmicas e pessoais comuns.

As minhas irmãs, Rosária e Raquel pelo apoio e incentivo à realização e conclusão do curso.

A minha esposa Giovana, e filhos Raíssa e Renan, que souberam compreender e apoiar nos momentos corretos, mostrando a importância do curso para nossas vidas.

A bibliotecária Eliana Maria Garcia, pela padronização da dissertação e correção das referências bibliográficas.

A Prof. Maria Helena Calafiori, que tanto contribuiu em minha vida acadêmica, sem medir esforços para a conclusão destes estudos, atuando em todas as fases. Quem a conhece sabe como é dificil lhe agradecer e descrever seu apoio, tendo sido a grande responsável por mais esta etapa vencida. 


\section{SUMÁRIO}

Página

RESUMO

ix

SUMMARY

xi

INTRODUÇÃO

2 REVISÃO DE LITERATURA

2.1 O Vírus da Mancha Anular.

2.20 vetor Brevipalpus phoenicis (Geijiskes, 1939)(Acari: Tenuipalpidae)

$2.3 \quad B$. phoenicis e a transmissão.............................................. 5

2.4 Ácaro e a relação com a adubação............................................ 6

$2.5 \quad$ B. phoenicis e o controle químico............................................. 7

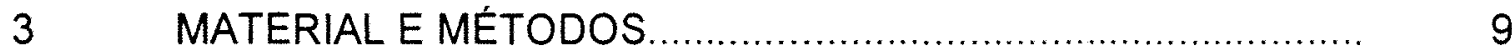

3.1 Composição química do solo, ocorrência do ácaro B. phoenicis e sintomas da MAC ............................................................. 9

3.1.1 Determinação de reboleiras............................................... 9

3.1.2 Coleta e análise de amostras............................................... 10

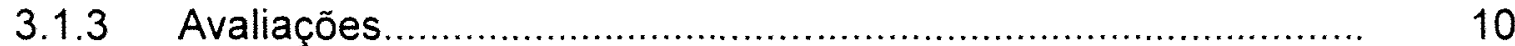

3.2 Efeito dos níveis de boro, cálcio, enxofre e zinco sobre a população de $B$ phoenicis e sintomas da MAC em cafeeiros adultos nas condições de campo ........................................... 11

3.2.1 Aplicação dos nutrientes.............................................. 11

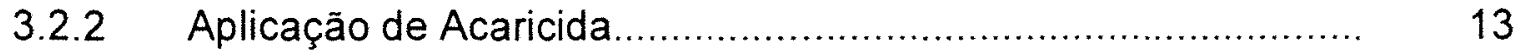

3.2.3 Varrição das plantas......................................................... 13 


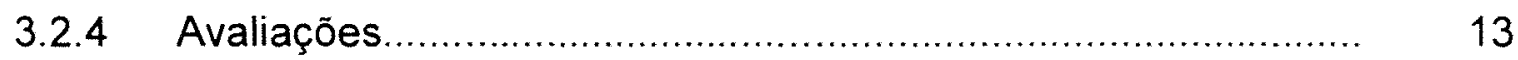

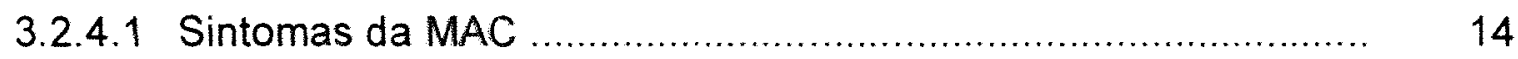

3.2.4.2 População de B. phoenicis ..................................................... 14

3.2.4.3 Comparação com o acaricida................................................... 15

3.2.4.4 Queda de frutos e folhas..................................................... 15

3.3 Efeito de diferentes níveis de enxofre aplicados via "Band-aid" em plantas de café nas condiçōes de campo............................ 15

3.3.1 Preparo e aplicação............................................................. 16

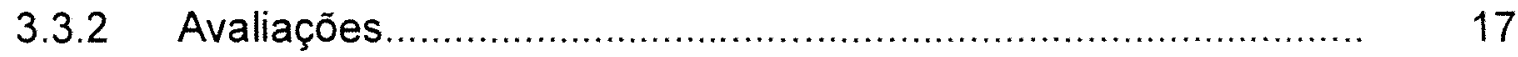

3.4 3.4 Estudo sobre diferentes sistemas de aplicação e absorção de enxofre em plantas de café............................................... 17

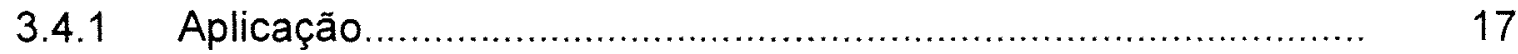

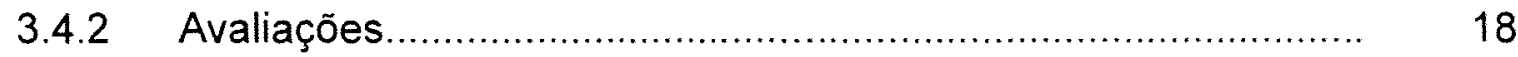

4 RESULTADOS E DISCUSSÃO .......................................... 19

4.1 Composição química do solo, ocorrência do ácaro B. phoenicis e sintomas da MAC ............................................................. 19

4.1.1 Levantamento químico do solo............................................. 19

4.2 Efeito dos niveis de boro, cálcio, enxofre e zinco sobre a população de $B$ phoenicis e sintomas da MAC em cafeeiros adultos nas condições de campo............................................. 21

4.2.1 Sintomas da MAC ............................................................... 21

4.2.2 Ocorrência de B. phoenicis ............................................... 25

4.2.3 Efeito de nutrientes e acaricida sobre a população do ácaro $B$. phoenicis e dos sintomas da MAC em cafeeiros adultos nas condições de campo.............................................................. 29

4.2.3.1 Sintomas da MAC ............................................................... 29

4.2.3.2 Ocorrência de B. phoenicis................................................... 33

4.2.4 Avaliação dos danos causados pelo ácaro plano devido a transmissão da MAC, e sua relação com a desfolha.................. 37

4.2.4.1 Número de folhas e frutos caídos.......................................... 37 
4.2.4.2 Porcentagem de desfolha .................................................. 38

4.3 Efeito de diferentes niveis de enxofre aplicados via "Band-aid" em plantas de café adultas nas condições de campo................. 39

4.3.1 Ensaio de Araguari, MG ................................................... 39

4.3.2 Ensaio em Espírito Santo do Pinhal - SP................................. 41

4.4 Diferentes sistemas de aplicação e absorção de enxofre em plantas de café......................................................................... 44

4.4.1 Análise do tecido vegetal................................................. 44

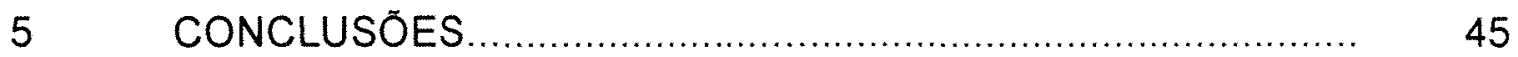

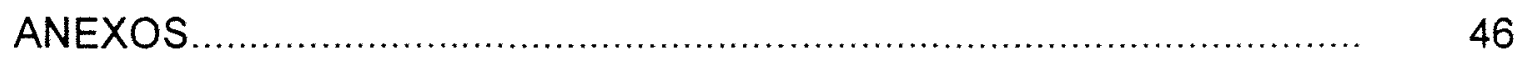

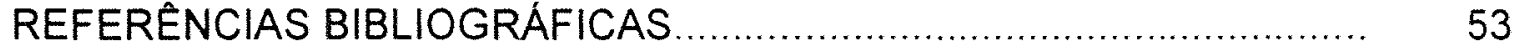




\title{
DESENVOLVIMENTO DO ÁCARO PLANO, Brevipalpus phoenicis, (GEIJISKES, 1939) E OCORRÊNCIA DA MANCHA ANULAR EM FUNÇÃO DE ALGUNS NUTRIENTES NO CAFEEIRO, Coffea arabica L.
}

\author{
Autor: Reymar Coutinho de Andrade \\ Orientador: Prof. Octávio Nakano
}

\section{RESUMO}

No final da década de noventa, a mancha anular do cafeeiro voltou a manifestar seus sintomas, após muito tempo desde a sua constatação. Este fato pode estar relacionado com as condições climáticas do período, manejo nutricional e fitossanitário adotado pelos produtores. O objetivo deste trabalho foi investigar a relação entre determinados nutrientes fornecidos ao cafeeiro e a ocorrência do ácaro $B$. phoenicis, transmissor do virus da mancha anular do cafeeiro, (MAC) e os sintomas dessa virose. Para tanto, foram conduzidos ensaios nas regiōes de Espírito Santo do Pinhal - SP e Araguari $M G$, onde foram testados os nutrientes $B, Z n$ e $S$ via solo, separadamente $e$ associados, relacionando-os à população do ácaro B. phoenicis e aos sintomas da virose, quantificados através de três avaliações mensais. Pôde-se verificar 
que plantas bem nutridas em enxofre e zinco com doses baixas de $B$ podem atuar como agente controlador do ácaro avaliado. A utilização de acaricidas, interferindo na população deste vetor, também, foi observada comparando-o aos diferentes nutrientes testados. Utilizando-se plantas na ausência desses micronutrientes, com a aplicação via foliar de Carbax (dicofol $160 \mathrm{~g} / \mathrm{l}+$ tetradifon $60 \mathrm{~g} / 1)$ houve redução da população de ácaros, porém aumentou o número de ovos encontrados. O efeito do acaricida foi superior ao do nutriente sobre o controle do ácaro plano. Coletando-se várias amostras de solo em áreas com plantas sobre forte manifestação dos sintomas da virose (reboleiras) e adjacentes sob um grau de infestação menor e após analisá-las, pode-se observar uma menor ocorrência destes sintomas ou de seu vetor, onde era maior o nivel de enxofre. A desfolha, em plantas marcadas com e sem aplicação de enxofre, foi quantificada após a eliminação das folhas caidas e com a contagem após 5 dias de novas folhas como, também, os frutos caídos. As plantas tratadas com enxofre apresentaram indice de desfolha menor. As folhas caidas estavam mais atacadas pela virose do que pelo bicho mineiro que também provoca queda de folhas e é uma praga chave do cafeeiro. A queda de frutos, diferente do ocorrido com a desfolha foi ligeiramente maior nas parcelas que receberam a aplicação de enxofre. Utilizando-se band-aids, com diferentes doses de enxofre, aplicados em plantas de café, observou-se que este elemento exerce um efeito sobre a presença do ácaro reduzindo assim a ocorrência da MAC, e nas maiores doses aplicadas foi encontrado o menor número de ácaros. Tais estudos evidenciaram que a presença de enxofre no solo, e sua aplicação em várias doses e de diferentes formas influenciaram o seu teor no tecido vegetal e consequentemente a presença do ácaro vetor e os sintomas causados, às plantas devido a ocorrência do vírus. Os resultados obtidos neste trabalho indicam que culturas bem nutridas e principaln em enxofre, podem apresentar tolerância ao ataque do vetor da MAC, e suas manifestaçōes. 


\title{
DEVELOPMENT OF THE FLAT MITE, Brevipalpus phoenicis, (GEIJISKES, 1939) AND OCCURRENCE OF THE COFFEE RINGSPOT IN RELATION TO SOME NUTRIENTS IN THE FERTILIZATION OF THE COFFEE PLANT, Coffea arabica L.
}

\author{
Author: Reymar Coutinho de Andrade \\ Adviser: Prof. Octávio Nakano
}

\section{SUMMARY}

This work deals with the relationship among some nutrients and the occurrence of the mite $B$. phoenicis, vector of the coffee ringspot virus and the symptoms of this disease. Some experiments were carried out in Espírito Santo do Pinhal - state of São Paulo, and Araguari - state of Minas Gerais to verify the influence of Boron, Zinc, Sulphur and acaricides on the mite population and symptoms of the disease. Low doses of Boron increased the symptoms. Carbax (dicofol $-160 \mathrm{~g} . / 1+$ tetradifon $-60 \mathrm{~g} . /$ ) reduced the mite population, but increased the number of eggs. The acaricide was better than nutrients, regarding mite control. Soil samples were collected at the crop sites places with many disease symptoms and without or with low number of diseased plants. The occurrence of ringspot was lower, where sulphur application was higher. Falling leaves and fruits under the plant were evaluated in areas with and without Sulphur application. There were low number of where 
the Sulphur level was the highest. This nutrient was applied also by a process called "Band-Aid" and a one observed lower mite population and therefore lower disease incidence. The results of all tests showed the efficiency of the coffee crop management, mainly with Sulphur application, to control the mite population and consequently the coffee ringspot virus incidence. 


\section{INTRODUÇÃO}

A cafeicultura mundial tem se expandido, ocupando novas áreas, novos países e novos mercados. O café, sempre foi considerado uma cultura de grande importância para o mundo, seu cultivo abriu fronteiras e desenvolveu um grande número de regiões. No Brasil, não foi diferente, pois é o maior produtor mundial possuindo a maior área plantada do mundo. Esta expansão exigiu cafeicultores mais tecnificados, utilizando grandes quantidades de insumos na busca de altas produções e rentabilidade. $O$ desequilibrio causado pelo uso errôneo de certos produtos promoveu a ocorrência de pragas que eram secundárias ou mesmo inexistentes nessa cultura. Paulini et al. (1975) já comentavam sobre o desequilibrio provocado pelos fungicidas aplicados para controle da ferrugem, aumentando a população do ácaro vermelho. Segundo D'Antoio et al. (1980), os piretróides, usados para controle do bicho-mineiro, também provocaram o mesmo efeito.

Muitas são as doenças que atacam o cafeeiro, como a "ferrugem" causada pelo fungo Hemileia vastatrix, e dentre as de etiologia viral encontra-se a "Mancha Anular do Cafeeiro" (MAC), descrita pela primeira vez por Bitancourt (1938). Esta doença afeta cafeeiros em qualquer idade de desenvolvimento, causando manchas cloróticas nas folhas em forma de anéis concêntricos ou alongados sobre as nervuras. Nos frutos, as manchas ocorrem em forma de anéis irregulares principalmente, próximas ao pedúnculo ficando posteriormente deprimidas; estas lesões promovem a queda de folhas e frutos, ficando estes com o pericarpo deformado dificultando o descascamento.

Esta virose tem como vetor o ácaro Brevipalpus phoenicis, estudado por Chagas (1973), que ocorre preferencialmente na parte interna e 
inferior das plantas, causando assim uma desfolha de dentro para fora, conhecida por "plantas ocas". Também, Bos (1983) associou a virose ao ácaro que ainda é vetor da "Pinta Verde do Maracujazeiro" (Kitajima et al., 1996) e "Leprose dos Citros" (Musumeci \& Rosstti,1963).

Desde a primeira observação desta moléstia na cultura do café, sua ocorrência se dá em reboleiras, não representando grandes prejuízos à cultura. A partir de 1996, esses focos aumentaram nas diversas regiōes produtoras bem como a sua intensidade, causando prejuízos significativos, principalmente, no cerrado mineiro, levando os produtores à aplicação de doses elevadas de acaricidas, muitos deles sem a recomendação oficial, apresentando baixas eficiências.

A nutrição das plantas, visando grandes produtividades com fórmulas inadequadas, tem causado um desequilibrio biológico onde pode-se observar a falta ou excesso de determinados nutrientes relacionados com a ocorrência de determinadas pragas, dentre elas o ácaro plano.

Como os conhecimentos sobre a relação entre o vírus da "mancha anular", ácaro plano e nutrientes na cultura do café ainda são escassos, o presente trabalho foi realizado visando trazer informaçōes quanto a sua ocorrência e seu aumento populacional, em função de diferentes niveis nutricionais do cafeeiro, bem como a utilização desses dados para uma recomendação prática de controle, em um sistema de manejo ecológico de pragas.

Assim, os estudos aqui abordados envolvem informações sobre: a composição química do solo em áreas atacadas pelo MAC (reboleiras); desenvolvimento da população de ácaros e sintomas de virose em relação aos diferentes niveis nutricionais do cafeeiro e controle do ácaro com acaricida; diferentes doses de enxofre e micronutrientes afetando a praga; quantificação de danos causados pelo "ácaro plano" devido a transmissão do virus e determinação da capacidade de absorção de enxofre em diferentes formas de aplicação, para diminuição da população de ácaro plano. 


\section{REVISÃO DE LITERATURA}

\subsection{O Virus da Mancha Anular}

Dentre as doenças de possível etiologia viral que atacam o cafeeiro está a "Mancha Anular", descrita pela primeira vez por Bitancourt (1938); o autor cita a semelhança com a murcha imaculada ou "spotted wilt". Esta primeira constatação ocorreu em cafeeiros de Caçapava - S.P. próximos às plantaçōes de tomate e citros. Posteriormente, esta moléstia também foi citada por Silberschimidt, (1941), dando indicações que esta virose pode ser transmitida por enxertia.

Os sintomas ocorrem em cafeeiros de diversas idades, causando manchas cloróticas em forma de anéis nas folhas e frutos, podendo estes ficar deprimidos com deformação no pericarpo (Chagas 1978). A constatação, por meio de microscopia eletrônica de partículas baciliformes em folhas afetadas, feita por Kitajima \& Costa (1972), mostrava semelhança à componente interna dos Rhabdovirus, deixando a hipótese de que a "Mancha Anular do Cafeeiro" seria de etiologia viral.

Com o aparecimento da ferrugem causada pelo fungo Hemileia vastatrix em 1970, a atenção dos produtores foi despertada para manchas presentes nas folhas dos cafeeiros. A virose "Mancha Anular" foi associada ao ácaro plano que transmitia a leprose dos citros e que já havia sido observado nessa cultura desde 1951 (Chagas, 1973). 


\subsection{O vetor Brevipalpus phoenicis (Geijiskes, 1939)(Acari: Tenuipalpidae).}

Este ácaro é conhecido pelos citricultores como "ácaro da leprose" por estar associado à leprose dos citros no Brasil (Musumeci \& Rossetti 1963). Tem sido relatado vivendo em cafezais pelo menos desde 1951 (A infestação...,1951) e tem se mostrado uma praga de grande interesse aos produtores de café nos últimos anos, por estar transmitindo virose que causa desfolha e queda de frutos em diversas regiões do Brasil, principalmente nos cerrados, onde as condições de seca (estiagem) favorecem a praga.

Segundo Chiavegato (1985), o ciclo desse acarino é muito influenciado pela temperatura, sendo que as mais elevadas favorecem o seu desenvolvimento. O mesmo autor constatou que o ciclo do ácaro é menor em frutos de laranja quando comparados aos criados sobre folhas. De acordo com os estudos realizados em pomares cítricos por Oliveira (1986), a partir dos meses de março - abril, período em que normalmente começam a diminuir as precipitações, os niveis populacionais de $B$. phoenicis se elevam, apresentando

picos nos meses de setembro - outubro e decrescendo gradativamente com o advento das chuvas.

Segundo Reis et al. (1997), em 1986, houve uma intensa desfolha do cafeeiro que foi associada a "mancha anular" e nesse período as condições foram favoráveis ao ácaro (inverno com baixa precipitação pluvial). A partir de 1990, e principalmente em 1995, o ácaro plano e a "mancha anular" voltaram a causar intensa desfolha nos cafezais do Alto do Paranaiba (Minas Gerais), tanto no arábica como no canéfora.

Matiello et al. (1996) relatam a ocorrência de "Leprose do cafeeiro" com a presença do ácaro $B$. phoenicis em plantas de conillon, cujos sintomas são diferentes dos descritos para a mancha anular tanto para C. arabica como para C. canephora.

Para Papa (1997), as safras cafeeiras do Triângulo Mineiro de 1995 e 1996 foram ameaçadas devido o ataque desse ácaro, constatando que 
$82 \%$ de frutos estavam infestados com uma média de 2,5 ácaros por fruto e os sintomas nas folhas eram semelhantes aos descritos por Chagas (1973).

Andrade et al. (1997 b) mostraram a relação entre a presença dessa praga com um sintoma de "cortiça" nos grãos de café, que pode ser utilizado como indicativo da presença deste ácaro na lavoura. REIS et al. (1997) observaram que $\circ B$. phoenicis além de estar associado à leprose dos citros está também à "mancha anular" do cafeeiro pelos sintomas, nas folhas, da doença e que esse ácaro estava presente em folhas, ramos, frutos onde havia a "cortiça". Concluíram ainda que os frutos atacados pelo ácaro estavam mais predispostos à penetração de microrganismos como Colletotrichum gloeosporioides.

\subsection{B. phoenicis e a transmissão}

Escassos são os relatos da transmissibilidade desse patógeno por esse ácaro em cafeeiro. Em citros, a transmissão da leprose no Brasil foi observada por Musumeci \& Rossetti (1963).

Rodrigues (1995) mostra que a taxa de transmissibilidade do isolado do patógeno da leprose pelo ácaro $B$. phoenicis foi de $10 \%$ e $11,1 \%$ e que após introdução do vírus por um ácaro adulto em laranja "Pêra" ocorre o aparecimento dos sintomas típicos da leprose dos citros em um período de 60 dias.

Chagas et al. (1983) verificaram que adultos deste ácaro apresentavam eficiência de transmissão desta doença de $7,6 \%$ e as ninfas de $8,7 \%$ e quando o ácaro se encontra na fase larval, $48,3 \%$, sugerindo que diferentes instares do vetor apresentavam diferentes eficiências de transmissão.

Experimentos realizados por Carvalho \& Figueira (1998), utilizando plantas hospedeiras, mostraram que isolados atuais do vírus estão apresentando características diferentes dos estudados a vinte anos atrás por 
Chagas (1978), que apresentavam lesōes locais nas plantas de Chenopodium quinoa e C. amaranticolor, indicando que os isolados atuais estariam apresentando características sistêmicas.

\section{4 Ácaro e a relação com a adubação}

O excesso ou a deficiência de nutrientes faz com que haja uma alteração no metabolismo da planta, provocando uma alteração das substâncias solúveis e aminoácidos livres, decorrentes da inibição da proteossintese ou excesso de produção de aminoácidos, favorecendo a alimentação dos insetos e ácaros (Chaboussou, 1987). A aplicação de fertilizantes na agricultura podem aumentar ou diminuir a população de insetos e ácaros, dependendo das espécies envolvidas devido aos elementos de sua composição (Pazzini e Parra, 1991).

Os ácaros necessitam encontrar, na planta hospedeira, alimentos solúveis, em forma de aminoácidos, açúcares e minerais. Quando o metabolismo da planta é alterado devido à ação de agrotóxicos e ou fertilizantes, pode ocorrer a proliferação desses organismos tendo por origem um aumento do seu potencial biótico, ou seja ocorre uma ação positiva, especialmente sobre a fecundidade, longevidade e velocidade de reprodução (Chaboussou, 1987).

Mellors e Propts (1983) observaram que niveis altos de N, NP e NK proporcionaram um aumento da população de $T$. urticae em rabanete.

Maia e Busoli (1992) estudaram os efeitos de diferentes doses de nitrogênio $(0,50,100,200$, e $300 \mathrm{ppm})$ fornecidas através de duas fontes (sulfato de amônio e nitrato de amônio ) sobre a fecundidade de $T$. urticae em folhas de algodoeiro cultivar IAC 20. Constaram que a adição de $S$ através do sulfato de amônio não alterou a duração do periodo de postura e a fecundidade total de fêmeas; entretanto, com o aumento das doses de $\mathrm{N}$ ocorreu uma 
redução na duração do período de pré - oviposição, um alongamento no período de postura e um aumento no número de ovos colocados por fêmea.

Ainda com ácaro rajado, Andrade et al. (1997 a) observaram que o enxofre no solo mais NPK induziram a uma maior população, enquanto, onde havia esterco de curral sua presença foi significativamente menor.

Sudoi et al. (1996), em condições de campo no Kenya, determinaram que aplicações de fertilizantes nitrogenados com enxofre afetaram o desenvolvimento do ácaro B. phoenicis em chá. Neste estudo os autores observaram uma redução na infestação de ácaros nas plantas, com a aplicação destes fertilizantes.

Durante levantamentos realizados no Triângulo Mineiro, Andrade \& Nakano (1998), através de amostragens de solo em áreas com ataque desse ácaro, observaram que a incidência estava relacionada com os teores de enxofre e que as áreas onde a presença de enxofre era maior, a ocorrência da mancha anular do cafeeiro e ácaro foram menores.

\subsection{B. phoenicis e o controle químico.}

Há uma grande dificuldade em se controlar este ácaro em cafeeiros, tendo em vista a disposição deste nas plantas bem como a arquitetura destas, obrigando o produtor a utilizar um alto volume de calda durante as pulverizações. Reis et al. (1997) mostraram que a maior população de ácaros encontra-se no terço inferior interno das plantas, e que para se obter um melhor controle, o equipamento deve depositar uma maior parte da calda nesta região.

Oliveira \& Reiff (1998 a e b), testando vários acaricidas em cafeeiros para o controle de $B$. phoenicis, notaram que a eficiência dos produtos foi muito maior sobre as folhas, do que em ramos, mostrando a dificuldade de se controlar os ácaros nos ramos por estarem menos expostos. Observaram 
também que alguns produtos, apenas, são eficientes quando utilizados em um volume de calda de $3000 \mathrm{I} / \mathrm{ha}$ e que dependendo do produto esta mesma eficiência pode ser alcançada a 1000 l/ha. 
3 MATERIAL E MÉTODOS

\subsection{Composição química do solo, ocorrência do ácaro $B$. phoenicis e sintomas da MAC}

\subsubsection{Determinação de reboleiras.}

Os levantamentos de áreas com incidência de MAC foram realizados em cafezais adultos das variedades Catuaí e Mundo Novo, localizados na Fazenda Santa Cecilia, situada no município de Araguari, estado de Minas Gerais, nos dias 13/10/1999 e 17/11/1999. Foram determinadas reboleiras de plantas que apresentavam os sintomas da virose, independente do número de plantas, porém considerando-se o grau de infestação. Foram consideradas reboleiras, as plantas que juntas apresentavam sintomas da virose no terço inferior, com um grau de infestação maior que $30 \%$ ou ocas (grande desfolha no interior) e onde, havia ocorrência de plantas com infestação inferior a $30 \%$ e sem plantas ocas foi considerada como área de baixa infestação. Estas plantas formaram grupos tanto na linha de plantio quanto em diversas linhas em que estes sintomas pudessem estar aparecendo, procurando-se encontrar grupos de plantas que apresentassem o mesmo grau de infestação. 


\subsubsection{Coleta e análise de amostras}

Após determinadas as "reboleiras", foram coletadas amostras de solo, dentro e fora das mesmas, de maneira que, se pudesse relacionar os niveis de fertilidade do solo com as plantas atacadas.

As amostras foram coletadas com auxilio de um enxadão à profundidade de 0 a $20 \mathrm{~cm}$, retirando-se um perfil uniforme de solo e identificadas separadamente, para mapeamento.

Foram realizadas análises químicas de fertilidade de solos em cada uma das amostras coletadas, no Departamento de Solos e Nutrição de Plantas da Escola Superior de Agricultura "Luiz de Queiroz", Piracicaba -SP, utilizando-se do método de extração pelo acetato de amônio $0,5 \mathrm{~N}$ em ácido acético $0,25 \mathrm{~N}$ para S-SO4, e extração DTPA-TEA pH 7,3 para os micronutrientes.

\subsubsection{Avaliações}

Com base nos resultados das análises, foram elaborados "croquis" que relacionassem os niveis de fertilidade às áreas com a maior ou menor ocorrência dos sintomas da MAC. 
3.2 Efeito dos niveis de boro, cálcio, enxofre e zinco sobre a população de B. phoenicis e sintomas da MAC em cafeeiros adultos nas condições de campo

\subsubsection{Aplicação dos nutrientes}

O ensaio foi instalado em lavoura adulta de café da variedade Catuai Vermelho, com espaçamento de $4 \times 0,8 \mathrm{~m}$, em 14 de julho de 1999, na Fazenda Santa Cecilia, municipio de Araguari, estado de Minas Gerais. O delineamento estatístico adotado foi o de blocos ao acaso com 9 tratamentos e 5 repetições. As parcelas eram constituidas por 7 plantas, sendo úteis as duas centrais. Os tratamentos foram: 1- Testemunha; 2- Boro; 3- Enxofre; 4- Zinco; 5Boro e Enxofre; 6- Boro e Zinco; 7- Enxofre e Zinco; 8- Boro, Enxofre e Zinco; 9Calagem. Como fonte dos elementos foram utilizados os produtos comerciais: Ácido Bórico 17,5\%, Kumulus -S 80\%, Ager Zinco Quelatizado 21\%(Cloreto de Zinco) e Calcário Calcinado Minercal $31 \% \mathrm{CaO}$ e $18 \% \mathrm{MgO}$.

Foram realizadas duas aplicações de nutrientes: 14 de julho de 1999 e 15 de outubro de 1999. Na primeira, as doses, por planta, utilizadas foram: ácido bórico 5,5g; Kumulus-S $8 \mathrm{~g}$; cloreto de zinco quelatizado 2,8ml; calcário calcinado $320 \mathrm{~g}$. A segunda aplicação foi realizada 93 dias após a primeira utilizando-se por planta: ácido bórico 2,25g; Kumulus-S $4 \mathrm{~g}$; cloreto de zinco quelatizado $1,4 \mathrm{ml}$ e calcário calcinado $160 \mathrm{~g}$.

Os nutrientes foram aplicados diretamente sob a projeção da copa das plantas de café (via solo), sendo a dose de zinco previamente diluída em água com volume de $250 \mathrm{ml}$ por planta (aplicação via "drench"). 
Tabela 1. Tratamentos, doses dos nutrientes no ensaio com café, ácaro plano, MAC e nutrientes.

\begin{tabular}{cccc}
\hline \multirow{2}{*}{ Tratamento } & \multirow{2}{*}{ Elemento } & \multicolumn{2}{c}{ Dose p.c./planta } \\
\cline { 3 - 4 } & & $1^{+}$aplicação & 2 aplicação \\
\hline 1 & Testemunha & -- &.- \\
3 & $\mathrm{~B}$ & $5.5 \mathrm{~g}$ & $2.25 \mathrm{~g}$ \\
4 & $\mathrm{~S}$ & $8 \mathrm{~g}$ & $4 \mathrm{~g}$ \\
5 & $\mathrm{Zn}$ & $2.8 \mathrm{ml}$ & $1.4 \mathrm{ml}$ \\
6 & $\mathrm{~B}+\mathrm{S}$ & $5.5 \mathrm{~g}+8 \mathrm{~g}$ & $2.25 \mathrm{~g}+4 \mathrm{~g}$ \\
7 & $\mathrm{~B}+\mathrm{Zn}$ & $5.5 \mathrm{~g}+2.8 \mathrm{ml}$ & $2.25 \mathrm{~g}+1.4 \mathrm{ml}$ \\
8 & $\mathrm{~S}+\mathrm{Zn}$ & $8 \mathrm{~g}+2.8 \mathrm{ml}$ & $4 \mathrm{~g}+1.4 \mathrm{ml}$ \\
9 & $\mathrm{~B}+\mathrm{S}+\mathrm{Zn}$ & $5.5 \mathrm{~g}+8 \mathrm{~g}+2.8 \mathrm{ml}$ & $2.25 \mathrm{~g}+4 \mathrm{~g}+1.4 \mathrm{ml}$ \\
\hline
\end{tabular}

Tabela 2. Produtos utilizados e suas concentrações utilizados no ensaio com café, ácaro plano, MAC e nutrientes.

\begin{tabular}{ccc}
\hline \multicolumn{3}{c}{ Produtos Utilizados } \\
\hline Elemento & Produto & Concentração \\
$\mathrm{B}$ & Ácido Bórico & $17,5 \%$ \\
$\mathrm{~S}$ & Kumulus - S & $80 \%$ \\
$\mathrm{ZnCl}$ & Ager Zinco (Quelatizado) & $21 \%$ \\
$\mathrm{CaO}+\mathrm{MgO}$ & Calcário Calcinado & $31 \%$ e $18 \%$ \\
\hline
\end{tabular}




\subsubsection{Aplicação de Acaricida}

Objetivando obter uma relação comparativa de eficiências, entre o controle químico com acaricida e os diversos niveis de nutrientes fornecidos, foram marcadas 4 parcelas sob área tratada com o acaricida Carbax (dicofol 160 $\mathrm{g} / \mathrm{l}+$ tetradifon $60 \mathrm{~g} / \mathrm{l})$ na dose de 1,5 //ha e volume de calda de $1000 \mathrm{l} / \mathrm{ha}$, no dia 20/10/1999, sendo a aplicação realizada com auxílio de um pulverizador tratorizado de arrasto com cortina de vácuo.

\subsubsection{Varrição das plantas}

Com auxilio de gadanho, foram varridas em 10/12/1999 e 19/03/2000, 13 plantas nutridas com enxofre e outras 13 sem, utilizadas como testemunha, retirando-se todas as folhas e materiais vegetais presentes abaixo destas. Após cinco dias, foram varridas novamente nove plantas de cada lote, desconsiderando-se duas plantas em cada uma das extremidades, deixadas como bordadura, para coleta de folhas e frutos.

\subsubsection{Avaliações}

As avaliações foram realizadas aos 91, 127 e 155 dias após o início da aplicação dos nutrientes, coletando-se 10 folhas por parcela no terço inferior, interno das plantas, acondicionando-as em sacos de papel. As amostras da área tratada com acaricida, foram coletadas juntamente com aquelas de 155 dias. Após cada coleta, as folhas foram transportadas em caixas de isopor com refrigeração à base de gelo até o laboratório de Entomologia, setor de defensivos agricolas, da Escola Superior de Agricultura Luiz de Queiroz, Piracicaba (S.P.), para avaliação da população do ácaro plano e da MAC. Os 
dados foram transformados em raiz de $x$ e raiz de $x+0,5$ para análise de variância e as médias foram comparadas pelo teste de Tukey a $5 \%$ (Banzatto \& Kronka 1989). A eficiência foi calculada pela fórmula de Abbott (1925).

\subsubsection{Sintomas da MAC}

Em cada parcela, foi contado o número de folhas com sintomas, o número de lesões por folha $e$, atribuiu-se notas para os diferentes níveis de infecção onde as mais elevadas representam os maiores niveis.

Tabela 3. Referência entre as notas atribuidas e a porcentagem de infestação da MAC em cada parcela.

\begin{tabular}{cc}
\hline Porcentagem $\%$ & Nota \\
\hline 0 a 20 & 1 \\
20 a 40 & 2 \\
40 a 60 & 3 \\
60 a 80 & 4 \\
80 a 100 & 5 \\
\hline
\end{tabular}

\subsubsection{População de B. phoenicis}

Com auxilio de lupa de $40 X$ de aumento, quantificou-se o número de folhas com a presença de ácaros, e o número de ácaros e ovos encontrados por folha, totalizando, por parcela. 


\subsubsection{Comparação com o acaricida}

Em 15/12/1999 foi realizada uma avaliação utilizando-se os mesmos parâmetros analisados durante as duas primeiras avaliaçōes, tanto para os sintomas da virose como para a população do ácaro e comparada aos tratamentos com nutrientes.

\subsubsection{Queda de frutos e folhas}

Com o material coletado após a segunda varrição de ambas as avaliações, foi quantificado o número de folhas caídas por queda natural, com sintomas de ataque de bicho mineiro, por outras causas e com os sintomas da mancha anular, calculando-se o índice de desfolha dos grupos de plantas com e sem enxofre. O número de frutos caídos, também, foi contado comparando a diferença em relação às plantas com e sem aplicação de enxofre.

\subsection{Efeito de diferentes niveis de enxofre aplicados via "Band-aid" em plantas de café, nas condições de campo}

Para melhor avaliar os efeitos dos teores de enxofre em cafeeiros, sobre o ácaro e os sintomas da MAC e baseando-se nos resultados dos ensaios já realizados, foram instalados outros com aplicação dirigida de enxofre em condições de campo, e em diferentes regiões cafeeiras como a do Triângulo Mineiro e Média Mogiana. O trabalho foi iniciado no dia 15/12/1999, na Fazenda Santa Cecilia município de Araguari (M.G.) e 21/12/1999 no "campus" I do Centro Regional Universitário de Espírito Santo do Pinhal, Espírito Santo do Pinhal (S.P.). 
Os ensaios foram instalados em lavoura adulta de café, variedade Catuai Vermelho, e o delineamento estatístico foi o de blocos ao acaso com cinco tratamentos e quatro repetições. Os tratamentos foram: 1) $0,25 \mathrm{~g}$ de enxofre; 2) $0,5 \mathrm{~g}$ de enxofre; 3) $1,0 \mathrm{~g}$ de enxofre; 4) $2,0 \mathrm{~g}$ de enxofre e 5) testemunha, sem aplicação do nutriente. Como fonte de enxofre foi utilizado, Enxofre a $98 \%$.

\subsubsection{Preparo e aplicação}

Para a aplicação direta do enxofre, foram preparados "Band-aids" nas diversas doses testadas. Os "Band-aids" foram confeccionados com uma fita adesiva e saches de pano contendo em seu interior a dose de enxofre desejada de acordo com o tratamento e uma quantidade padrão de gel granulado, este último para manter o enxofre disponivel ao longo do tempo, após absorver água (Figura 1).

Foram marcados, em quatro plantas alternadas, no terço inferior, cinco ramos por planta, e retiradas as folhas que apresentavam sintomas da virose, onde cada planta foi considerada como repetição. Foram aderidos a cada um dos ramos um "Band-aid", aplicando-se a respectiva dose a cada ramo (tratamento), deixando-se um ramo marcado e sem aplicação de "Band-aid" (testemunha), depois de colocados os adesivos estes foram regados com água para que o gel absorvendo a mesma, levasse as partículas do enxofre para liberação gradual, através da casca do ramo. 


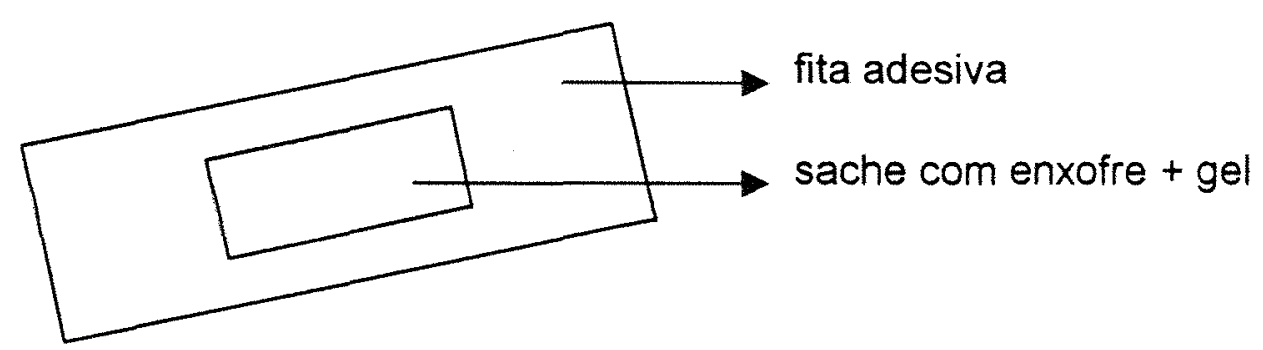

Figura 1- Esquema do "Band-aid"

\subsubsection{Avaliações}

Foram realizadas duas avaliaçōes: em 24/02/00 e 24/03/00 no ensaio instalado na fazenda Santa Cecília, Araguari - MG e em 02/03/2000 e 30/03/2000 no ensaio do Centro Regional Universitário de Espírito Santo do Pinhal, Espirito Santo do Pinhal - SP, quantificando-se a incidência da virose e o número de ácaros, nos respectivos tratamentos.

3.4 Estudo sobre diferentes sistemas de aplicação e absorção de enxofre em plantas de café

\subsubsection{Aplicação}

Com o intuito de obter um conhecimento maior da real absorção do enxofre pelas plantas de café, nas diferentes formas de aplicação utilizadas e suas diferentes formulaçōes, instalou -se um ensaio em 18 de julho de 2000 em uma lavoura de café adulta com aproximadamente 25 anos, variedade Mundo Novo e espaçamento $4 \times 2 \mathrm{~m}$ com duas plantas por cova no "Campus I" do Centro Regional Universitário de Espírito Santo do Pinhal, em Espírito Santo do 
Pinhal -SP. O delineamento experimental adotado foi o de blocos ao acaso, com 5 tratamentos e 4 repetições. As parcelas experimentais eram compostas por 6 plantas, sendo úteis as duas plantas centrais (cova), fornecendo $6,4 \mathrm{~g}$ de enxofre por planta em diferentes formas de aplicação e produtos. Os tratamentos foram: 1- Testemunha sem aplicação; 2- Calda sulfocálcica via foliar; 3- Kumulus-S via foliar; 4- Kumulus-S $80 \%$ via "drench"; 5- Enxofre $98 \%$ via "Band-aid".

\subsubsection{Avaliações}

Para avaliar a quantidade de enxofre absorvida pelas plantas de café nos diferentes tratamentos, foram coletados $\circ 3^{\circ}$ e $4^{\circ}$ pares de folhas na altura mediana das plantas totalizando 20 folhas por parcela, que foram lavadas com água pura e secas à sombra, submetendo-as a análise de niveis nutricionais do elemento, aos 90 dias após a aplicação. 


\section{RESULTADOS E DISCUSSÃO}

4.1 Relação entre a composição química do solo, ocorrência do ácaro $B$. phoenicis e dos sintomas da MAC

\subsubsection{Levantamento químico do solo}

Nas análises de solo das áreas amostradas, observou-se redução da incidência dos sintomas, com aumento dos niveis de $S$. O centro das reboleiras está representado, pelos menores niveis de enxofre encontrados nas amostras de solo coletadas e maior incidência de virose (Figura 2 e 3 ).

Em função dos dados obtidos, não se pode determinar um nivel de enxofre que sirva de limiar para a menor ocorrência destes sintomas, mas podese observar que a partir de uma variação encontrada no solo dos niveis de enxofre, existe uma maior ou menor incidência da doença e que quanto maior for esta variação, mais pronunciados se tornam os limites das reboleiras. (Figura 4).

Assim, pode-se deduzir que a menor ocorrência dos sintomas da virose, esta relacionada com a presença do enxofre. 


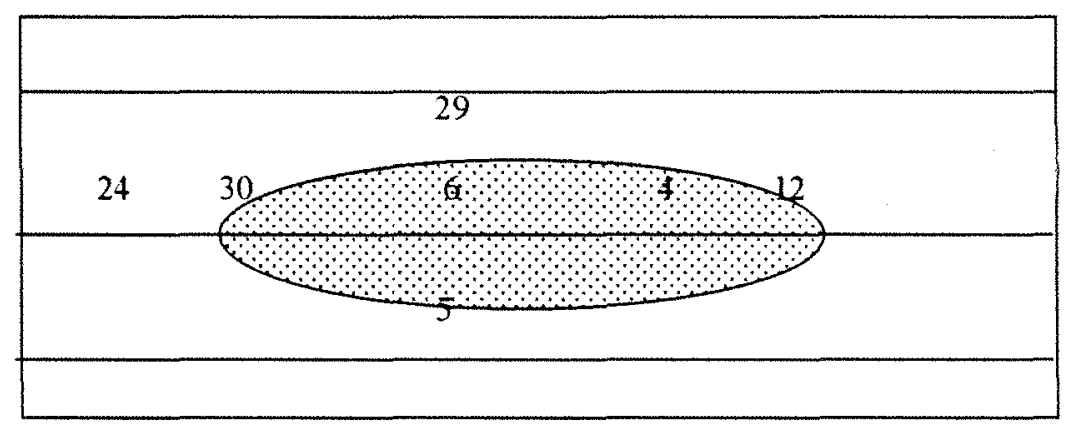

(i) Reboleira com maior incidência da virose.

Valores referência no quadro em $\mathrm{mg} \mathrm{dm^{-3 }}$ de $S$ no solo.

Figura 2 - Sintomas da MAC representados em amarelo com os números em $\mathrm{mg} / \mathrm{dm}^{3}$ de "S" no solo. Araguarí MG, 13/10/1999.

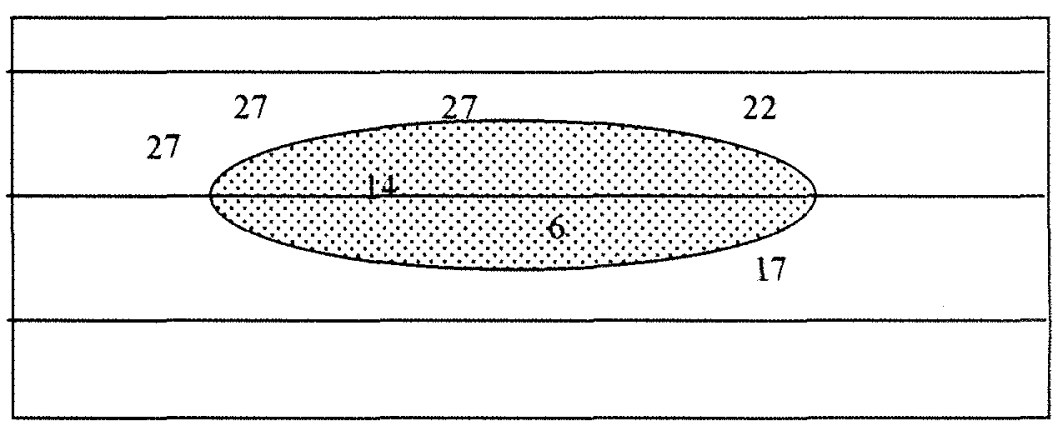

$\rightarrow$ Reboleira com maior incidência da virose.

Valores referência no quadro em $\mathrm{mg} \mathrm{dm}^{-3}$ de $\mathrm{S}$ no solo

Figura 3 - Sintomas da MAC representados em amarelo com os números em $\mathrm{mg} / \mathrm{dm}^{3}$ de "S" no solo. Araguari MG, 17/11/1999. 


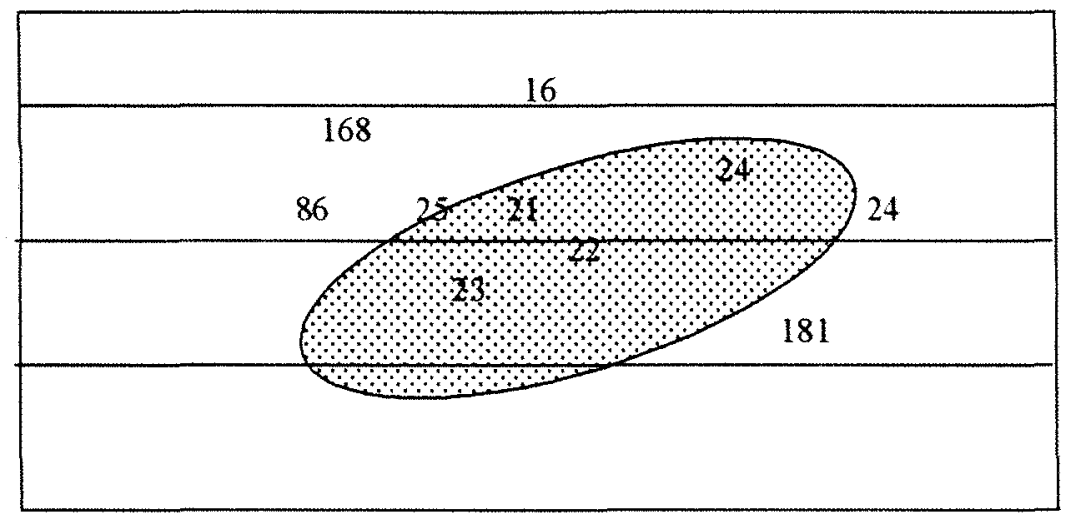

$\$$ Reboleira com maior incidência da virose.

Valores referência no quadro em $\mathrm{mg} \mathrm{dm}^{-3}$ de $\mathrm{S}$ no solo

Figura 4 - Sintomas da MAC representados em amarelo com os números em $\mathrm{mg} / \mathrm{dm}^{3}$ de "S" no solo. Araguarí MG, 17/11/1999.

4.2 Efeito dos niveis de boro, cálcio, enxofre e zinco sobre a população do ácaro plano e sintomas da MAC em cafeeiros adultos nas condições de campo

\subsubsection{Sintomas da MAC}

Os sintomas da MAC nas folhas foram observados com maior freqüência nos tratamentos onde ocorreu a aplicação de boro, na ausência de adubação e naquele com calagem (Tabela 4)(Figura 5). Mesmo nos tratamentos 
onde houve a aplicação de enxofre ou zinco associado a boro a presença desses sintomas foi maior.

Nos tratamentos com zinco e enxofre, tanto isoladamente como em associação, os sintomas da MAC foram menores (Tabela 4)(Figura 5).

$\mathrm{Na}$ avaliação realizada em novembro verificou-se que mesmo com aumento dos sintomas, a aplicação de enxofre e zinco reduziu o número de folhas atacadas (Tabela 4)(Figura 5).

Quanto ao número de lesões de MAC por folha (Tabela 5)(Figura 6), os resultados foram semelhantes mostrando a maior incidência de sintomas nos tratamentos sem adubação, com calagem e com boro.

Tabela 4. Número médio de folhas com sintomas da MAC em ensaio com diferentes nutrientes, Araguari-MG, 1999.

\begin{tabular}{cccccccccc}
\hline \multirow{2}{*}{ Trat } & \multicolumn{3}{c}{$12 / 10 / 1999$} & \multicolumn{3}{c}{$17 / 11 / 1999$} & \multicolumn{3}{c}{$15 / 12 / 1999$} \\
\cline { 2 - 9 } & Média & Tukey & EF\% & Média & Tukey & EF\% & Média & Tukey & EF\% \\
\hline 1 & 5,00 & 2,180 a & --- & 6,00 & 2,413 abc & -- & 3,20 & 2,115 a & -- \\
2 & 5,70 & 2,345 a & $-8,00$ & 5,40 & 2,306 abc & 10,00 & 3,80 & 2,284 a & $-18,75$ \\
3 & 4,80 & 2,252 a & 4,00 & 2,60 & 1,576 a & 56,67 & 1,60 & 1,465 a & 50,00 \\
4 & 2,00 & 1,392 a & 60,00 & 3,80 & 1,867 abc & 36,67 & 1,40 & 1,409 a & 56,25 \\
5 & 2,80 & 1,716 a & 44,00 & 4,40 & 2,048 abc & 26,67 & 3,40 & 2,134 a & $-6,25$ \\
6 & 3,60 & 1,999 a & 28,00 & 7,00 & 2,627 c & $-16,67$ & 1,20 & 1,168 a & 62,50 \\
7 & 2,60 & 1,699 a & 48,00 & 3,00 & 1,636 ab & 50,00 & 1,80 & 1,580 a & 43,75 \\
8 & 2,00 & 1,421 a & 60,00 & 5,00 & 2,187 abc & 16,67 & 1,60 & 1,548 a & 50,00 \\
9 & 5,60 & 2,409 a & $-12,00$ & 6,20 & 2,471 bc & $-3,33$ & 1,40 & 1,409 a & 56,25 \\
F. & 1,133 n.s. & & & $4,013 * *$ & & & $2,550 *$ & \\
C.V. & $32,65 \%$ & & & $19,51 \%$ & & & $29,42 \%$ & \\
DMS & 1,320 & & & 0,872 & & & 1,188 & \\
\hline
\end{tabular}

* significativo a $5 \%$

** significativo a $1 \%$

ns não significativo 
Tabela 5. Número médio de lesões da MAC por parcela em ensaio com diferentes nutrientes, Araguari-MG, 1999.

\begin{tabular}{|c|c|c|c|c|c|c|c|c|c|}
\hline \multirow{2}{*}{ Trat } & \multicolumn{3}{|c|}{$12 / 10 / 1999$} & \multicolumn{3}{|c|}{$17 / 11 / 1999$} & \multicolumn{3}{|c|}{$15 / 12 / 1999$} \\
\hline & Média & Tukey & $E F \%$ & Média & Tukey & $\overline{E F \%}$ & Média & Tukey & $E F \%$ \\
\hline 1 & 40,40 & $5,398 a$ & -- & 30,00 & 5,044 bc & - & 11,20 & $3,661 \mathrm{a}$ & $-\ldots$ \\
\hline 2 & 29,00 & $4,935 \mathrm{a}$ & 28,22 & 14,80 & $3,735 \mathrm{abc}$ & 50,67 & 19,25 & $4,414 \mathrm{a}$ & $-37,50$ \\
\hline 3 & 22,20 & $4,288 a$ & 45,05 & 7,60 & $2,496 a b$ & 74,67 & 3,25 & $1,758 a$ & 76,78 \\
\hline 4 & 6,00 & $2,058 \mathrm{a}$ & 85,15 & 11,60 & $2,981 \mathrm{abc}$ & 61,33 & 5,75 & $2,071 \mathrm{a}$ & 58,93 \\
\hline 5 & 5,20 & $2,185 \mathrm{a}$ & 87,13 & 10,00 & $3,025 \mathrm{abc}$ & 66,67 & 15,75 & $3,880 \mathrm{a}$ & $-12,50$ \\
\hline 6 & 9,00 & $2,936 \mathrm{a}$ & 77,72 & 30,20 & $5,208 \quad \mathrm{c}$ & $-0,67$ & 5,00 & $1,662 a$ & 64,29 \\
\hline 7 & 5,40 & $2,310 \mathrm{a}$ & 86,63 & 4,60 & $1,953 \mathrm{a}$ & 84,67 & 3,25 & $1,797 \mathrm{a}$ & 76,79 \\
\hline 8 & 3,80 & $1,714 \mathrm{a}$ & 90,59 & 22,20 & $4,362 a b c$ & 26,00 & 2,50 & $1,673 a$ & 82,14 \\
\hline 9 & 25,60 & 4,551 a & 36,63 & 18,40 & $4,201 a b c$ & 38,67 & 4,75 & $2,022 \mathrm{a}$ & 66,07 \\
\hline F. & & 2,709 * & & & $4,274^{\star \star}$ & & & 3,630 * & \\
\hline C.V. & & $56,89 \%$ & & & $33,36 \%$ & & & $45,44 \%$ & \\
\hline DMS & & 4,036 & & & 2,517 & & & 2,785 & \\
\hline
\end{tabular}

* significativo a $5 \%$

** significativo a $1 \%$

ns não significativo

As avaliações mostram um diferencial na intensidade dos sintomas da MAC. Uma única lesão clorótica recobrindo grande porcentagem da área foliar foi freqüente, sendo quantificada por uma escala de notas que representa esta porcentagem. Desta forma, foi possivel constatar que a falta de adubação e o fornecimento de boro isoladamente estavam relacionados com as parcelas mais atacadas percentualmente, porém a presença de zinco reduziu esta porcentagem (Tabela 6)(Figura 7). 
Tabela 6. Notas referentes à porcentagem de incidência da MAC nas folhas em diferentes épocas, em ensaio com diferentes nutrientes, Araguari-MG, 1999.

\begin{tabular}{cccccccccc}
\hline \multirow{2}{*}{ Trat } & \multicolumn{3}{c}{$12 / 10 / 1999$} & \multicolumn{3}{c}{$17 / 11 / 1999$} & \multicolumn{3}{c}{$15 / 12 / 1999$} \\
\cline { 2 - 9 } & Média & Tukey & EF\% & Média & Tukey & EF\% & Média & Tukey & EF\% \\
\hline 1 & 2,20 & $1,559 \mathrm{a}$ & --- & 2,40 & $1.512 \mathrm{a}$ & -- & 1,75 & $1,475 \mathrm{~b}$ & -- \\
2 & 2,20 & $1,605 \mathrm{a}$ & 0,00 & 1,40 & $1.166 \mathrm{a}$ & 41,67 & 2,00 & $1,564 \mathrm{~b}$ & $-14,29$ \\
3 & 1,60 & $1,425 \mathrm{a}$ & 27,27 & 1,40 & $1.146 \mathrm{a}$ & 41,67 & 0,75 & $1,095 \mathrm{ab}$ & 57,14 \\
4 & 0,60 & $1,018 \mathrm{a}$ & 72,73 & 1,20 & $1.083 \mathrm{a}$ & 50,00 & 1,00 & $1,184 \mathrm{ab}$ & 42,86 \\
5 & 0,80 & $1,121 \mathrm{a}$ & 63,64 & 1,20 & $1.083 \mathrm{a}$ & 50,00 & 2,00 & $1,564 \mathrm{~b}$ & $-14,29$ \\
6 & 1,00 & $1,225 \mathrm{a}$ & 54,54 & 2,40 & $1.493 \mathrm{a}$ & 0,00 & 0,25 & $0,837 \mathrm{a}$ & 85,71 \\
7 & 1,00 & $1,225 \mathrm{a}$ & 54,54 & 1,00 & $1.000 \mathrm{a}$ & 58,33 & 0,75 & $1,095 \mathrm{ab}$ & 57,14 \\
8 & 0,60 & $1,018 \mathrm{a}$ & 72,73 & 2,40 & $1.476 \mathrm{a}$ & 0,00 & 1,75 & $1,449 \mathrm{ab}$ & 0,00 \\
9 & 1,60 & $1,425 \mathrm{a}$ & 27,27 & 1,80 & $1.312 \mathrm{a}$ & 25,00 & 0,75 & $1,095 \mathrm{ab}$ & 57,14 \\
F. & 3,033 * & & & $2,077 \mathrm{n.s}$. & & $4,107^{*}$ & \\
C.V. & $22,05 \%$ & & & $24,71 \%$ & & & $20,19 \%$ & \\
DMS & 0,60 & & & 0,65 & & & 0,61 & \\
\hline
\end{tabular}

* significativo a $5 \%$

** significativo a $1 \%$

ns não significativo 


\subsubsection{Ocorrência de B. phoenicis}

A presença do ácaro plano, também, variou nos diferentes tratamentos em função dos nutrientes aplicados.

Nas avaliações que quantificaram o número de folhas com ácaros, observou-se um maior número de folhas atacadas nos tratamentos sem adubação e na presença de boro isoladamente ou associado ao zinco e enxofre, que corresponde a ocorrência da MAC nestes tratamentos.

Os sintomas desta virose podem estar relacionados com uma maior presença de boro nas folhas, afetando a preferência e desenvolvimento dos ácaros e não sobre o vírus; no entanto, o boro atua no aumento do ácido indol acético, que em maior quantidade reduz o ácido abcísico (Mengel e Kirkby, 1987), causando retenção de folhas nas plantas. Assim, mesmo folhas atacadas pelo vírus permanecem mais tempo nas plantas, o que pode explicar um maior ataque.

O número de folhas com ácaros foi menor na presença de enxofre associado a boro e a zinco, nas avaliações de 12/10/1999 e 17/11/1999, e no tratamento com enxofre somente (Tabela 7)(Figura 8).

A maior população desse ácaro por folha foi observada na ausência de adubação e na associação de zinco com boro e este isoladamente (Tabela 8)(Figura 9), confirmando os resultados obtidos quanto ao número de folhas com ácaros (Tabela 7)(Figura 8).

A quantidade de ovos de $B$. phoenicis encontrada nas parcelas variou de acordo com a aplicação dos nutrientes (Tabela 9)(Figura10), tendo sido encontrado um número maior de ovos na ausência de adubação e nas áreas tratadas com associação de boro, zinco e enxofre.

Os tratamentos com maior quantidade de cálcio, devido a calagem realizada no início do ensaio, e sem adubação com os elementos testados, pouco influenciaram na ocorrência dos ácaros bem como dos sintomas da virose, ficando em algumas avaliações semelhantes à testemunha. 
Tabela 7. Número médio de folhas com ácaro, B. phoenicis, em ensaio com diferentes nutrientes, Araguari-MG, 1999.

\begin{tabular}{|c|c|c|c|c|c|c|c|c|c|}
\hline \multirow{2}{*}{ Trat } & \multicolumn{3}{|c|}{$12 / 10 / 1999$} & \multicolumn{3}{|c|}{$17 / 11 / 1999$} & \multicolumn{3}{|c|}{$15 / 12 / 1999$} \\
\hline & Média & Tukey & EF\% & Média & Tukey & EF\% & Média & Tukey & EF\% \\
\hline 1 & 3,80 & $2,015 a$ & -- & 6,20 & $2,479 \mathrm{~b}$ & -- & 2,00 & $1,498 \mathrm{a}$ & $-\ldots$ \\
\hline 2 & 2,20 & $1,605 \mathrm{a}$ & 42,10 & 3,40 & $1,794 a b$ & 45,16 & 2,75 & $1,772 \mathrm{a}$ & $-37,50$ \\
\hline 3 & 3,00 & $1,819 a$ & 21,05 & 2,80 & $1,659 a$ & 54,84 & 1,50 & $1,386 a$ & 25,00 \\
\hline 4 & 3,20 & $1,856 \mathrm{a}$ & 15,79 & 4,40 & $2,084 a b$ & 29,03 & 1,00 & $1,184 a$ & 50,00 \\
\hline 5 & 1,60 & $1,380 \mathrm{a}$ & 57,89 & 4,60 & $2,131 \mathrm{ab}$ & 25,81 & 3,25 & $1,891 \mathrm{a}$ & $-62,50$ \\
\hline 6 & 3,40 & $1,924 \mathrm{a}$ & 10,53 & 6,40 & $2,509 b$ & $-3,23$ & 1,25 & 1,257 a & 37,50 \\
\hline 7 & 2,20 & $1,500 \mathrm{a}$ & 42,10 & 3,40 & $1,802 a b$ & 45,16 & 1,75 & $1,418 \mathrm{a}$ & 12,50 \\
\hline 8 & 1,80 & $1,443 a$ & 52,63 & 3,80 & $1,878 \mathrm{ab}$ & 38,71 & 2,25 & $1,654 \mathrm{a}$ & $-12,50$ \\
\hline 9 & 2,80 & $1,792 \mathrm{a}$ & 26,32 & 6,40 & $2,518 b$ & $-3,23$ & 1,50 & $1,346 \mathrm{a}$ & 25,00 \\
\hline F. & \multicolumn{3}{|c|}{1,003 n.s. } & \multicolumn{3}{|c|}{$4,404^{\star \star}$} & \multicolumn{3}{|c|}{1,117 n.s. } \\
\hline C.V. & \multicolumn{3}{|c|}{$29,82 \%$} & \multicolumn{3}{|c|}{$17,19 \%$} & \multicolumn{3}{|c|}{$30,17 \%$} \\
\hline DMS & \multicolumn{3}{|c|}{1,068} & \multicolumn{3}{|c|}{0,757} & \multicolumn{3}{|c|}{1,081} \\
\hline
\end{tabular}

** significativo a $1 \%$

ns não significativo 
Tabela 8. Número médio de ácaros, B. phoenicis, por parcela em ensaio com diferentes nutrientes, Araguari-MG, 1999.

\begin{tabular}{ccccccccccc}
\hline \multirow{2}{*}{ Trat } & \multicolumn{3}{c}{$12 / 10 / 1999$} & \multicolumn{3}{c}{$17 / 11 / 1999$} & \multicolumn{3}{c}{$15 / 12 / 1999$} \\
\cline { 2 - 9 } & Média & Tukey & EF\% & Média & Tukey & EF\% & Média & Tukey & EF\% \\
\hline 1 & 5,00 & 2,295 a & --- & 10,00 & 3,125 & c & --- & 2,75 & 1,705 a & -- \\
2 & 3,20 & 1,873 a & 36,00 & 4,20 & 1,980 ab & 58,00 & 3,25 & 1,924 a & $-18,18$ \\
3 & 4,20 & 2,110 a & 16,00 & 3,40 & 1,823 a & 66,00 & 2,00 & 1,538 a & 27,27 \\
4 & 4,00 & 2,042 a & 20,00 & 6,00 & 2,427 abc & 40,00 & 1,50 & 1,363 a & 45,45 \\
5 & 1,80 & 1,415 a & 64,00 & 5,40 & 2,303 abc & 46,00 & 4,00 & 2,060 a & $-45,45$ \\
6 & 5,20 & 2,284 a & $-4,00$ & 9,80 & 3,060 bc & 2,00 & 1,50 & 1,319 a & 45,45 \\
7 & 2,40 & 1,550 a & 52,00 & 4,80 & 2,125 abc & 52,00 & 2,75 & 1,689 a & 0,000 \\
8 & 3,00 & 1,745 a & 40,00 & 5,20 & 2,210 abc & 48,00 & 2,25 & 1,726 a & 9,09 \\
9 & 3,60 & 1,965 a & 28,00 & 9,40 & 3,026 bc & 6,00 & 2,00 & 1,507 a & 27,27 \\
F. & 1,133 n.s. & & $4,452 * *$ & & & 0,851 n.s. & \\
C.V. & $32,65 \%$ & & & $21,37 \%$ & & & $32,16 \%$ & \\
DMS & 1,320 & & & 1,102 & & & 1,275 & \\
\hline
\end{tabular}

** significativo a $1 \%$

ns não significativo 
Tabela 9. Número médio de ovos de $B$. phoenicis por parcela em ensaio com diferentes nutrientes, Araguari-MG, 1999.

\begin{tabular}{cccccccccc}
\hline \multirow{2}{*}{ rrat } & \multicolumn{3}{c}{$12 / 10 / 1999$} & \multicolumn{3}{c}{$17 / 11 / 1999$} & \multicolumn{3}{c}{$15 / 12 / 1999$} \\
\cline { 2 - 9 } & Média & Tukey & EF\% & Média & Tukey & EF\% & Média & Tukey & EF\% \\
\hline 1 & 1,00 & 1,192 a & -- & 1,60 & 1,425 a & -- & 0,50 & 0,966 a & $-\cdots$ \\
2 & 0,40 & 0,914 a & 60.00 & 1,00 & 1,192 a & 37,50 & 0,00 & 0,707 a & 100,00 \\
3 & 0,40 & 0,914 a & 60.00 & 0,80 & 1,089 a & 25,00 & 0,00 & 0,707 a & 100,00 \\
4 & 0,60 & 0,985 a & 40.00 & 0,80 & 1,089 a & 37,50 & 0,25 & 0,837 a & 50,00 \\
5 & 0,40 & 0,914 a & 60.00 & 0,60 & 0,985 a & 0,00 & 0,50 & 0,966 a & 0,00 \\
6 & 1,00 & 1,160 a & 0.00 & 1,00 & 1,192 a & 12,50 & 0,00 & 0,707 a & 100,00 \\
7 & 0,80 & 1,089 a & 20.00 & 1,20 & 1,197 a & 50,00 & 0,25 & 0,837 a & 50,00 \\
8 & 0,00 & 0,707 a & 100.00 & 0,80 & 1,089 a & 37,50 & 0,25 & 0,837 a & 50,00 \\
9 & 0,20 & 0,811 a & 80.00 & 1,20 & 1,264 a & 18,75 & 0,25 & 0,837 a & 50,00 \\
F. & 1,287 n.s. & & 1,595 n.s. & & 0,767 n.s. & \\
C.V. & $32,59 \%$ & & & $17,60 \%$ & & & $28,09 \%$ & \\
DMS & 0,661 & & & 0,619 & & & 0,555 & \\
\hline
\end{tabular}




\subsubsection{Efeito de nutrientes e acaricida sobre a população do ácaro $B$. phoenicis e dos sintomas da MAC em cafeeiros adultos nas condições de campo}

\subsubsection{Sintomas da MAC}

O acaricida pouco influenciou nos resultados referentes aos sintomas da virose, pois, a menor ocorrência esteve relacionada com a presença de zinco mais enxofre, enxofre somente e calagem. Nos tratamentos com boro, associado ou não, ausência de adubação (Tabela 10)(Figura 11) e com acaricida foi encontrada a maior porcentagem de infestação da doença, mostrando um maior controle do vetor pelos nutrientes do que pelo acaricida.

O tratamento com boro mais zinco mais enxofre mostrou uma eficiência acima de $80 \%$ na diminuição do número de lesões da virose (Tabela 11)(Figura 12), enquanto a do acaricida foi de $37,50 \%$.

Como nas folhas ocorreram muitas lesões, porém muito pequenas e assim afetando menos a área foliar em relação a outras que eram em menor número porém grandes, foi feita a escala de notas (Tabela 12)(Figura 13). Por essa escala pode-se observar uma infestação menor onde foram aplicados boro e zinco associados, com eficiência acima de $85 \%$. A eficiência do acaricida foi de $28,57 \%$.

O acaricida não tem influência sobre a virose, porém, pode ter efeito sobre seu vetor, o ácaro plano e em conseqüência diminui o sintoma. Contudo para que isso ocorra o efeito de choque do produto químico deve ser muito alto o que nem sempre acontece. 
Tabela 10. Número médio de folhas com sintomas do vírus da mancha anular do café em ensaio com diferentes nutrientes e aplicação de acaricida, Araguari-MG, 1999.

\begin{tabular}{cccc}
\hline \multirow{2}{*}{ Trat } & \multicolumn{3}{c}{$15 / 12 / 1999$} \\
\cline { 2 - 4 } & Média & Tukey & EF\% \\
\hline 1 & 3,20 & $2.115 \mathrm{a}$ & --- \\
2 & 3,80 & $2.284 \mathrm{a}$ & $-18,75$ \\
3 & 1,60 & $1.465 \mathrm{a}$ & 50,00 \\
4 & 1,40 & $1.409 \mathrm{a}$ & 56,25 \\
5 & 3,40 & $2.134 \mathrm{a}$ & $-6,25$ \\
6 & 1,20 & $1.168 \mathrm{a}$ & 62,50 \\
7 & 1,80 & $1.580 \mathrm{a}$ & 43,75 \\
8 & 1,60 & $1.548 \mathrm{a}$ & 50,00 \\
9 & 1,40 & $1.409 \mathrm{a}$ & 56,25 \\
10 & 2,60 & $1924 \mathrm{a}$ & 18,75 \\
F. & \multicolumn{3}{c}{$2.320 *$} \\
C.V. & \multicolumn{3}{|}{$29,27 \%$} \\
DMS & & 1,213 \\
\hline
\end{tabular}

* $\quad$ significativo a $5 \%$ 
Tabela 11. Número de lesões do vírus da mancha anular do café por parcela, em ensaio com diferentes nutrientes e acaricidas, Araguari-MG, 1999.

\begin{tabular}{cccc}
\hline \multirow{2}{*}{ rat } & \multicolumn{3}{c}{$15 / 12 / 1999$} \\
\cline { 2 - 4 } & Média & Tukey & EF\% \\
\hline 1 & 11,20 & $3.661 \mathrm{a}$ & --- \\
2 & 19,25 & $4.414 \mathrm{a}$ & $-37,50$ \\
3 & 3,25 & $1.758 \mathrm{a}$ & 76,78 \\
4 & 5,75 & $2.071 \mathrm{a}$ & 58,93 \\
5 & 15,75 & $3.880 \mathrm{a}$ & $-12,50$ \\
6 & 5,00 & $1.662 \mathrm{a}$ & 64,29 \\
7 & 3,25 & $1.797 \mathrm{a}$ & 76,79 \\
8 & 2,50 & $1.673 \mathrm{a}$ & 82,14 \\
9 & 4,75 & $2.022 \mathrm{a}$ & 66,07 \\
10 & 8,75 & $2.865 \mathrm{a}$ & 37,50 \\
F. & & $3.002 *$ & \\
C.V. & & $46,09 \%$ & \\
DMS & & 2,911 &
\end{tabular}

* significativo a $5 \%$ 
Tabela 12. Notas referentes a porcentagem de ataque dos sintomas da MAC em ensaio com diferentes nutrientes e acaricidas, Araguari-MG, 1999.

\begin{tabular}{cccc}
\hline \multirow{2}{*}{ Trat } & \multicolumn{3}{c}{$15 / 12 / 1999$} \\
\cline { 2 - 4 } & Média & Tukey & EF\% \\
\hline 1 & 1,75 & $1.475 \mathrm{~b}$ & --- \\
2 & 2,00 & $1.564 \mathrm{~b}$ & $-14,29$ \\
3 & 0,75 & $1.095 \mathrm{ab}$ & 57,14 \\
4 & 1,00 & $1.184 \mathrm{ab}$ & 42,86 \\
5 & 2,00 & $1.564 \mathrm{~b}$ & $-14,29$ \\
6 & 0,25 & $0.837 \mathrm{a}$ & 85,71 \\
7 & 0,75 & $1.095 \mathrm{ab}$ & 57,14 \\
8 & 1,75 & $1.449 \mathrm{ab}$ & 0,00 \\
9 & 0,75 & $1.095 \mathrm{ab}$ & 57,14 \\
10 & 1,25 & $1.314 \mathrm{ab}$ & 28,57 \\
F. & \multicolumn{3}{c}{$3.550 * *$} \\
C.V. & \multicolumn{3}{c}{$20,44 \%$} \\
DMS & 0,630 \\
\hline
\end{tabular}

** significativo a $1 \%$ 


\subsubsection{Ocorrência de B. phoenicis}

Diferente do observado quanto a ocorrência da virose, as parcelas tratadas com Carbax (dicofol + tetradifon) mostraram eficiência no controle do ácaro, atingindo até $75 \%$ (Tabela 13 e 14)(Figura 14 e 15), porém, houve aumento da quantidade de ovos encontrados nas folhas (Tabela 15 )(Figura 16). $O$ acaricida controlou o ácaro, porém, não com a rapidez necessária para evitar que ele deixasse o vírus na planta; isso explica a diferença entre eficiência sobre a praga e sobre a virose.

Os tratamentos com boro, enxofre e associação de boro e zinco apresentaram menor número de ovos, enquanto com acaricida foi maior, devido a ação do acaricida sobre os adultos. Pelos resultados observa-se a necessidade de aplicaçōes de acaricidas antes do período de pico populacional do ácaro, utilizando-se produtos que tenham também ação ovicida, reduzindo assim a possibilidade de uma reinfestação e a aplicação dos nutrientes boro e enxofre ou associação de boro e zinco para diminuição do número de ovos. Uma nutrição rica em enxofre e zinco ao longo do ano agricola pode estar influenciando adultos e ninfas de $B$. phoenicis e conseqüentemente na redução dos sintomas da MAC. 
Tabela 13. Número médio de folhas com ácaro B. phoenicis em ensaio com diferentes nutrientes e acaricida, Araguari-MG, 1999.

\begin{tabular}{cccc}
\hline \multirow{2}{*}{ Trat } & \multicolumn{3}{c}{$15 / 12 / 1999$} \\
\cline { 2 - 4 } & Média & Tukey & EF\% \\
\hline 1 & 2,00 & $1,498 \mathrm{a}$ & -- \\
2 & 2,75 & $1,772 \mathrm{a}$ & $-37,50$ \\
3 & 1,50 & $1,386 \mathrm{a}$ & 25,00 \\
4 & 1,00 & $1,184 \mathrm{a}$ & 50,00 \\
5 & 3,25 & $1,891 \mathrm{a}$ & $-62,50$ \\
6 & 1,25 & $1,257 \mathrm{a}$ & 37,50 \\
7 & 1,75 & $1,418 \mathrm{a}$ & 12,50 \\
8 & 2,25 & $1,654 \mathrm{a}$ & $-12,50$ \\
9 & 1,50 & $1,346 \mathrm{a}$ & 25,00 \\
10 & 0,50 & $0,966 \mathrm{a}$ & 75,00 \\
F. & \multicolumn{3}{c}{1,648 n.s. } \\
C.V. & \multicolumn{3}{c}{$30,18 \%$} \\
DMS & \multicolumn{3}{c}{1,055}
\end{tabular}

n.s. não significativo 
Tabela 14. Número médio de ácaros $B$. phoenicis por parcela em ensaio com diferentes nutrientes e acaricida, Araguari-MG, 1999.

\begin{tabular}{cccc}
\hline \multirow{2}{*}{ Trat } & \multicolumn{3}{c}{$15 / 12 / 1999$} \\
\cline { 2 - 4 } & Média & Tukey & EF\% \\
\hline 1 & 2,75 & $1,705 \mathrm{a}$ & -- \\
2 & 3,25 & $1,924 \mathrm{a}$ & $-18,18$ \\
3 & 2,00 & $1,538 \mathrm{a}$ & 27,27 \\
4 & 1,50 & $1,363 \mathrm{a}$ & 45,45 \\
5 & 4,00 & $2,060 \mathrm{a}$ & $-45,45$ \\
6 & 1,50 & $1,319 \mathrm{a}$ & 45,45 \\
7 & 2,75 & $1,689 \mathrm{a}$ & 0,000 \\
8 & 2,25 & $1,726 \mathrm{a}$ & 9,09 \\
9 & 2,00 & $1,507 \mathrm{a}$ & 27,27 \\
10 & 0,75 & $1,055 \mathrm{a}$ & 72,73 \\
F. & \multicolumn{3}{c}{1,314 n.s. } \\
C.V. & $32,63 \%$ \\
DMS & \multicolumn{3}{c}{1,261} \\
\hline
\end{tabular}

ns não significativo 
Tabela 15. Número médio de ovos de B. phoenicis por parcela em ensaio com diferentes nutrientes e acaricida, Araguari-MG, 1999.

\begin{tabular}{cccc}
\hline \multirow{2}{*}{ Trat } & \multicolumn{3}{c}{$15 / 12 / 1999$} \\
\cline { 2 - 4 } & Média & Tukey & EF\% \\
\hline 1 & 0,50 & $0,966 \mathrm{a}$ & $\cdots$ \\
2 & 0,00 & $0,707 \mathrm{a}$ & 100,00 \\
3 & 0,00 & $0,707 \mathrm{a}$ & 100,00 \\
4 & 0,25 & $0,837 \mathrm{a}$ & 50,00 \\
5 & 0,50 & $0,966 \mathrm{a}$ & 0,00 \\
6 & 0,00 & $0,707 \mathrm{a}$ & 100,00 \\
7 & 0,25 & $0,837 \mathrm{a}$ & 50,00 \\
8 & 0,25 & $0,837 \mathrm{a}$ & 50,00 \\
9 & 0,25 & $0,837 \mathrm{a}$ & 50,00 \\
10 & 0,75 & $0,998 \mathrm{a}$ & $-50,00$ \\
F. & \multicolumn{3}{c}{0,598 n.s. } \\
C.V. & \multicolumn{3}{c}{$0,93 \%$ \% } \\
DMS & \multicolumn{3}{c}{0,694} \\
\hline
\end{tabular}

n.s. não significativo 


\subsubsection{Avaliação dos danos causados pelo ácaro plano devido a transmissão da MAC, e sua relação com a desfolha}

\subsubsection{Número de folhas e frutos caidos}

Pelos resultados obtidos com o levantamento de queda de folhas e frutos, observou-se em duas amostragens uma menor queda de folhas devido aos sintomas da virose nas ruas onde houve a aplicação de enxofre via solo (Quadro 1), tanto no mês de dezembro como em março, porém, sendo mais expressiva em dezembro. Considerou-se como queda natural as folhas que não apresentavam sinais de ataque de pragas e doenças. A queda de frutos foi maior nas plantas onde houve a aplicação de enxofre, quando comparadas com as sem aplicação, nas amostragens de 15/12/99 e 23/03/00.

\begin{tabular}{|l|c|c|c|c|c|}
\hline Fator de queda & $\begin{array}{c}\text { Folhas cl } \\
\text { virose }\end{array}$ & $\begin{array}{c}\text { Queda } \\
\text { natural }\end{array}$ & $\begin{array}{c}\text { Folhas } \\
\text { velhas }\end{array}$ & $\begin{array}{c}\text { Bicho } \\
\text { mineiro }\end{array}$ & Frutos \\
\hline Rua A 15/12/99 & 98 & 144 & 171 & 76 & 1339 \\
\hline Rua B 15/12/99 & 130 & 217 & 97 & 51 & 1080 \\
\hline Rua C 23/03/00 & 72 & 145 & 216 & 58 & 1045 \\
\hline Rua D 23/03/00 & 83 & 164 & 208 & 53 & 982 \\
\hline
\end{tabular}

$\square$ Rua com aplicação de enxofre $\quad \square$ Rua sem aplicação

Quadro 1- Número de frutos e folhas caídos em 9 plantas de café, durante 5 dias, Araguari -MG. 


\subsubsection{Porcentagem de desfolha}

Considerando-se o número total de folhas caídas (Quadro 2), há uma maior porcentagem de folhas velhas e com queda natural, quando comparadas as que sofreram o ataque do ácaro; porém, este, causou uma maior desfolha do que a $L$. coffeella (Quadro 2), considerada praga chave em café.

Em dezembro, a porcentagem de queda de folhas em função da virose onde não havia sido aplicado enxofre foi de $6,22 \%$, maior do que nas áreas com aplicação deste elemento (Quadro 2).

A desfolha causada pela virose foi maior no levantamento realizado em dezembro quando comparado ao de março, mostrando que ela está relacionada com o pico populacional do ácaro e a possivel latência que este vírus apresenta em cafeeiros.

\begin{tabular}{|c|c|c|c|c|}
\hline Fator de queda & $\begin{array}{c}\text { Folhas } \mathrm{cl} \\
\text { virose } \%\end{array}$ & $\begin{array}{c}\text { Queda natural } \\
\%\end{array}$ & $\begin{array}{c}\text { Folhas velhas } \\
\%\end{array}$ & $\begin{array}{c}\text { bicho mineiro } \\
\%\end{array}$ \\
\hline Rua A 15/12/99 & 20,0409 & 29,44785 & 34,96933 & 15,54192 \\
\hline Rua B 15/12/99 & 26,26263 & 43,83838 & 19,59596 & 10,30303 \\
\hline Rua C 23/03/00 & 14,66395 & 29,53157 & 43,99185 & 11,81263 \\
\hline Rua D 23/03/00 & 16,33858 & 32,28346 & 40,94488 & 10,43307 \\
\hline
\end{tabular}

$\square$ Rua com aplicação de enxofre

Rua sem aplicação

Quadro 2 - Porcentagem de folhas caídas em 9 plantas de café, durante 5 dias, Araguari-MG. 
4.3 Efeito de diferentes niveis de enxofre aplicados via "Band-aid" em plantas de café nas condições de campo

\section{3.i Ensaio de Araguari, MG}

Os resultados das diferentes doses de enxofre testadas em aplicação direta (via, Band-aid) mostram que as maiores populações do ácaro ocorreram nos tratamentos com aplicação de $0.25 \mathrm{~g}$ de enxofre e sem aplicação (Tabela 16 )(Figura 19), onde também surgiram os sintomas da MAC (Tabela 17)(Figura 17).

Os tratamentos com doses superiores a $1,0 \mathrm{~g}$ de enxofre mantiveram populações mais baixas, em 30 dias, e aquele com $2,0 \mathrm{~g}$ não permitiu o aumento da população de ácaros durante 60 dias, mostrando que o enxofre atua sobre o desenvolvimento de populações de $B$. phoenicis, no cafeeiro, com eficiência de $71,43 \%$.

O número de folhas com sintomas do MAC foi menor no tratamento com $2 \mathrm{~g}$ de $\mathrm{S}$, com eficiência superior a $90 \%$, aos 30 dias da aplicação (Tabela 17)(Figura 17).

O mesmo aconteceu com o número de manchas nas folhas (Tabela 18)(Figura 18). A dose de 1g, aos 30 dias, obteve eficiência acima de $80 \%$, em número de manchas, e $72 \%$ para número de folhas com sintomas da virose. 
Tabela 16. Número de ácaros em cinco folhas por ramo amostradas ao acaso, em ensaio aplicando-se doses de enxofre através de "Band-aid", Araguari - MG

\begin{tabular}{|c|c|c|c|c|c|c|}
\hline \multirow{2}{*}{ Trat. } & \multicolumn{3}{|c|}{$24 / 02 / 2000$} & \multicolumn{3}{|c|}{$24 / 03 / 2000$} \\
\hline & Média & Tukey & EF\% & Média & Tukey & EF\% \\
\hline 1 & 2,25 & $1,160 \mathrm{a}$ & $-12,50$ & 1,75 & $1,492 \mathrm{a}$ & 0,00 \\
\hline 2 & 1,50 & $1,319 a$ & 25,00 & 1,00 & $1,184 \mathrm{a}$ & 42,86 \\
\hline 3 & 0,75 & $1,095 \mathrm{a}$ & 62,50 & 1,50 & $1,346 \mathrm{a}$ & 14,27 \\
\hline 4 & 0,75 & $1,095 \mathrm{a}$ & 62,50 & 0,50 & $0,966 \mathrm{a}$ & 71,43 \\
\hline 5 & 2,00 & $1,564 \mathrm{a}$ & - & 1,75 & $1,475 a$ & -- \\
\hline $\mathrm{F}$. & & 1,782 n.s & & & 2,376 n.s & \\
\hline C.V. & & $27,65 \%$ & & & $22,13 \%$ & \\
\hline DMS & & 0,834 & & & 0,645 & \\
\hline
\end{tabular}

n.s. não significativo

Tabela 17. Número de folhas com sintoma da MAC em cinco folhas por ramo amostradas ao acaso, em ensaio aplicando-se doses de enxofre através de "Band-aid", Araguari - MG

\begin{tabular}{|c|c|c|c|c|c|c|}
\hline \multirow{2}{*}{ Trat. } & \multicolumn{3}{|c|}{$24 / 02 / 2000$} & \multicolumn{3}{|c|}{$24 / 03 / 2000$} \\
\hline & Média & Tukey & EF\% & Média & Tukey & $\mathrm{EF} \%$ \\
\hline 1 & 2,25 & $1,470 a$ & 18,18 & 2,75 & $1,640 \quad b$ & 0,00 \\
\hline 2 & 1,75 & $1,375 \mathrm{a}$ & 36,36 & 1,00 & $1,000 \mathrm{a}$ & 63,636 \\
\hline 3 & 0,75 & $1,095 a$ & 72,73 & 2,25 & $1,457 \quad b$ & 18,182 \\
\hline 4 & 0,25 & 0,837 a & 90,91 & 1,00 & $1,000 \mathrm{a}$ & 63,636 \\
\hline 5 & 2,75 & $1,798 \mathrm{a}$ & -- & 2,75 & $1,640 \quad b$ &.-- \\
\hline F. & & 1.736 n.s. & & & 10.385 & \\
\hline C.V. & & $42.36 \%$ & & & $15.01 \%$ & \\
\hline DMS & & 1,256 & & & 0,456 & \\
\hline
\end{tabular}


Tabela 18. Número de manchas nas folhas por parcela da MAC em cinco folhas por ramo amostradas ao acaso, em ensaio aplicando-se doses de enxofre através de "Band-aid", Araguari-MG.

\begin{tabular}{|c|c|c|c|c|c|c|}
\hline \multirow{2}{*}{ Trat. } & \multicolumn{3}{|c|}{$24 / 02 / 2000$} & \multicolumn{3}{|c|}{$24 / 03 / 2000$} \\
\hline & Média & Tukey & EF\% & Média & Tukey & $E F \%$ \\
\hline 1 & 6,00 & $2,116 a$ & $-9,09$ & 4,50 & $2,104 \quad b$ & 0,00 \\
\hline 2 & 5,75 & $2,215 \mathrm{a}$ & $-4,55$ & 1,25 & $1,104 \mathrm{a}$ & 72,22 \\
\hline 3 & 1,00 & $1,184 a$ & 8,82 & 4,75 & $2,127 \quad b$ & $-5,56$ \\
\hline 4 & 0,25 & 0,837 a & 95,45 & 1,25 & $1,104 \mathrm{a}$ & 72,22 \\
\hline 5 & 5,50 & $2,427 \mathrm{a}$ & --- & 4,50 & $2,073 \quad b$ & --- \\
\hline F. & & 1,878 n.s. & & & 7,872 ** & \\
\hline C.V. & & $58,22 \%$ & & & $22,90 \%$ & \\
\hline DMS & & 2,305 & & & 0,879 & \\
\hline
\end{tabular}

* * significativo a $1 \%$

ns não significativo

\subsubsection{Ensaio em Espírito Santo do Pinhal - SP}

A população de ácaros em Espirito Santo do Pinhal-S.P. (Tabela 19)(Figura 22) era menor, comparando-se com aquela de Araguari MG, e portanto as influências foram mais altas. Os resultados se repetem sendo a dose de $2 \mathrm{~g}$, a mais eficiente no controle, aos 30 dias, atingindo $100 \%$.

O número de folhas com sintoma e o número de manchas por folha (Tabelas 20 e 21)(Figura 20 e 21) também são menores no tratamento com 2 gramas aos 30 dias, com uma eficiência de $100 \%$.

Em testes realizados em casa de vegetação, com mudas, estas doses de enxofre foram tóxicas às plantas e os ramos utilizados nas plantas 
adultas, após 120 dias da aplicação, também apresentaram sintomas de intoxicação, indicando que esta substância foi absorvida pela planta e em determinadas doses, apesar da eficiência no controle da praga, estas podem ser prejudiciais à planta. Deve-se encontrar a dose ideal de eficiência de controle sem ocorrer fitotoxidade.

Tabela 19. Número de ácaros em cinco folhas por ramo amostrado ao acaso, em ensaio aplicando-se doses de enxofre através de "Band-aid", Espírito Santo do Pinhal - SP.

\begin{tabular}{|c|c|c|c|c|c|c|}
\hline \multirow{2}{*}{ Trat. } & \multicolumn{3}{|c|}{$02 / 03 / 2000$} & \multicolumn{3}{|c|}{$30 / 03 / 2000$} \\
\hline & Média & Tukey & EF\% & Média & Tukey & EF\% \\
\hline 1 & 0,50 & $0,966 a$ & 33,33 & 0,75 & $1,055 \mathrm{a}$ & 25,00 \\
\hline 2 & 0,75 & $1,055 \mathrm{a}$ & 0,000 & 0,75 & $1,095 \mathrm{a}$ & 25,00 \\
\hline 3 & 0,50 & $0,966 \mathrm{a}$ & 33,33 & 0,50 & 0,966 a & 50,00 \\
\hline 4 & 0,00 & $0,707 a$ & 100,00 & 0,50 & 0,966 a & 50,00 \\
\hline 5 & 0,75 & $1,055 \mathrm{a}$ & -- & 1,00 & $1,184 a$ & --- \\
\hline F. & & 0,653 n.s. & & & 0,510 n.s. & \\
\hline C.V. & & $37,21 \%$ & & & $24,61 \%$ & \\
\hline DMS & & 0,797 & & & 0,584 & \\
\hline
\end{tabular}

n.s. não significativo 
Tabela 20. Número de folhas com sintoma da MAC em cinco folhas por ramo amostradas ao acaso, em ensaio aplicando-se doses de enxofre através de "Band-aid", Espirito Santo do Pinhal - SP.

\begin{tabular}{|c|c|c|c|c|c|c|}
\hline \multirow{2}{*}{ Trat. } & \multicolumn{3}{|c|}{$02 / 03 / 2000$} & \multicolumn{3}{|c|}{$30 / 03 / 2000$} \\
\hline & Média & Tukey & EF\% & Média & Tukey & EF\% \\
\hline 1 & 0,50 & $0,926 a$ & 0,00 & 1,00 & $1,144 \mathrm{a}$ & 0.000 \\
\hline 2 & 0,50 & $0,926 \mathrm{a}$ & 0,00 & 0,50 & $0,966 \mathrm{a}$ & 50.00 \\
\hline 3 & 0,25 & $0,837 a$ & 50,00 & 0,75 & $1,055 \mathrm{a}$ & 25.00 \\
\hline 4 & 0,00 & $0,707 a$ & 100,00 & 0,50 & 0,966 a & 50.00 \\
\hline 5 & 0,50 & 0,966 a & -- & 1,00 & $1,184 a$ & --- \\
\hline F. & & 0,341 n.s. & & & 0,267 n.s. & \\
\hline C.V. & & $40,70 \%$ & & & $36,49 \%$ & \\
\hline DMS & & 0,797 & & & 0,875 & \\
\hline
\end{tabular}

n.s. não significativo

Tabela 21. Número de manchas da MAC em cinco folhas por ramo amostradas ao acaso, em ensaio aplicando-se doses de enxofre através de "Band-aid", Espírito Santo do Pinhal - SP.

\begin{tabular}{|c|c|c|c|c|c|c|}
\hline \multirow{2}{*}{ Trat. } & \multicolumn{3}{|c|}{$02 / 03 / 2000$} & \multicolumn{3}{|c|}{$30 / 03 / 2000$} \\
\hline & Média & Tukey & EF\% & Média & Tukey & EF\% \\
\hline 1 & 0,75 & $0,998 \mathrm{a}$ & 0,00 & 1,00 & $1,144 \mathrm{a}$ & 20,00 \\
\hline 2 & 0,75 & $0,998 a$ & 0,00 & 0,75 & $1,055 \mathrm{a}$ & 40,00 \\
\hline 3 & 0,25 & $0,837 a$ & 66,67 & 0,75 & $1,055 \mathrm{a}$ & 40,00 \\
\hline 4 & 0,00 & $0,707 a$ & 100,00 & 0,75 & $1,055 \mathrm{a}$ & 40,00 \\
\hline 5 & 0,75 & $1,055 \mathrm{a}$ & -- & 1,25 & $1,257 \mathrm{a}$ & --- \\
\hline $\mathrm{F}$. & & 0,402 n.s & & & 0,157 n.s. & \\
\hline C.V. & & $49,36 \%$ & & & $40,46 \%$ & \\
\hline DMS & & 1,023 & & & 1,015 & \\
\hline
\end{tabular}

n.s. não significativo 


\subsection{Diferentes sistemas de aplicação e absorção de enxofre em plantas de café}

\subsubsection{Análise de tecido vegetal}

Utilizando-se os dados da análise química do tecido vegetal (Tabela 22), nota-se que o acréscimo nos teores de enxofre foi pequeno. Esse fato pode ser explicado pela ocorrência de fitotoxidade em experiências anteriores em casa de vegetação com doses maiores, o que levou a aplicações de doses menores neste ensaio. No entanto, esta pequena diferença permite observar que os tratamentos Calda Sulfocálcica e Kumulus-S via foliar apresentaram melhores resultados de absorção seguido por aplicações via solo e "Band-aid" que podem ter sido prejudicadas pela estiagem ocorrida após o período de aplicação ou pela formulação. Comparados à testemunha, todos os tratamentos apresentaram pequeno aumento nos teores de enxofre.

Como já era esperado, o tratamento com Calda Sulfocálcica, único a fornecer Ca via foliar, elevou o teor deste elemento em grandes proporções.

Tabela 22. Teores de enxofre (S) e cálcio ( $\mathrm{Ca}$ ) em folhas de cafeeiros em Espirito Santo do Pinhal- SP

\begin{tabular}{ccc}
\hline \multirow{2}{*}{ Tratamentos } & \multicolumn{2}{c}{ Teores dos elementos em $\mathrm{g} / \mathrm{kg}$} \\
\cline { 2 - 3 } & $\mathrm{S}$ & $\mathrm{Ca}$ \\
\hline 1 & 1.73 & 6.22 \\
2 & 2.32 & 9.39 \\
3 & 2.65 & 5.49 \\
4 & 2.08 & 6.94 \\
5 & 1.81 & 7.35 \\
\hline
\end{tabular}




\section{CONCLUSÕES}

A nutrição das plantas rica em enxofre e zinco, com doses mais moderadas de boro, de maneira a suprir as necessidades fisiológicas da planta atua como agente controlador do ácaro plano em cafezais, desde que a dose não seja fitotóxica.

O controle deve ser iniciado quando a população do ácaro é baixa com menor incidência da virose.

Culturas com bom manejo nutricional e fitossanitário, são menos atacadas por esta virose.

A aplicação do S através de "Band-aid" ou outra forma assimilável desse nutriente contribui para o controle do ácaro.

A presença de $\mathrm{B}$ e $\mathrm{Zn}$ associados, contribuem para uma menor infestação dos sintomas da MAC. 
ANEXOS 


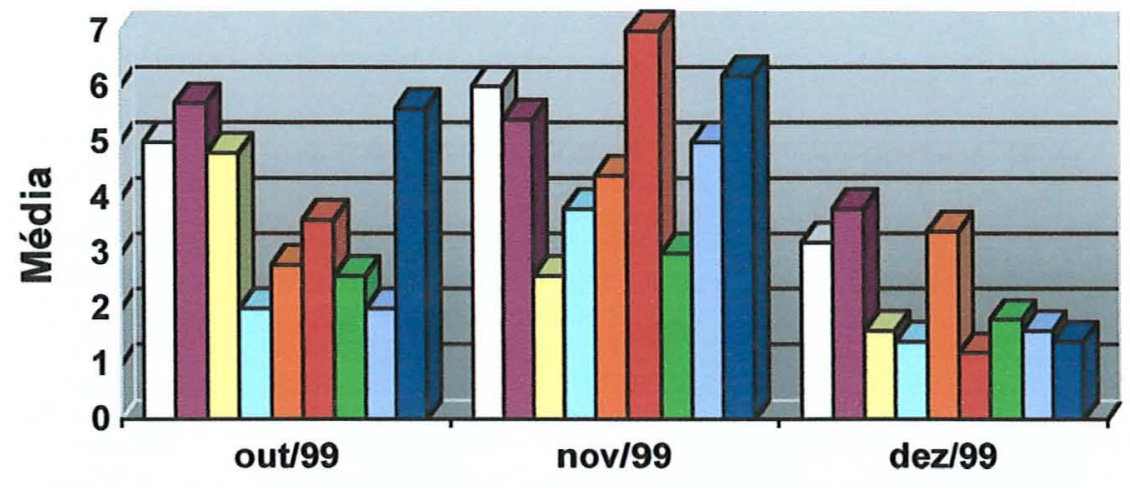

TTest. $\square \mathrm{B} \square \mathrm{S} \square \mathrm{Zn} \square \mathrm{B}+\mathrm{S} \square \mathrm{B}+\mathrm{Zn} \square \mathrm{S}+\mathrm{Zn} \square \mathrm{B}+\mathrm{S}+\mathrm{Zn} \square$ Calcário

Figura 5 - Número médio de folhas com sintomas da MAC, Araguari-MG, 1999.

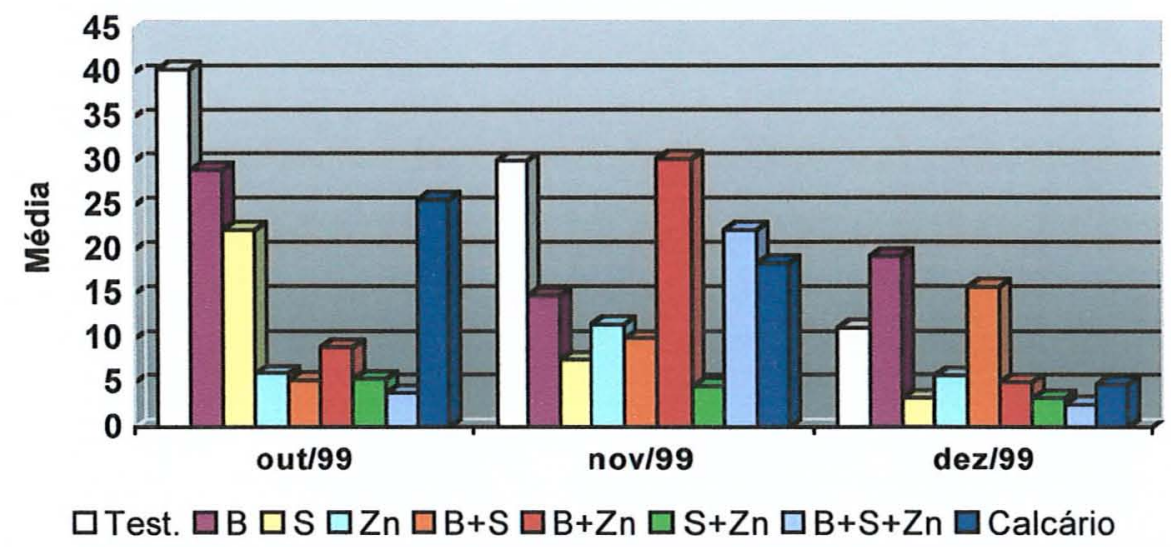

Figura 6 - Número médio de lesões da MAC por parcela, Araguari-MG, 1999.

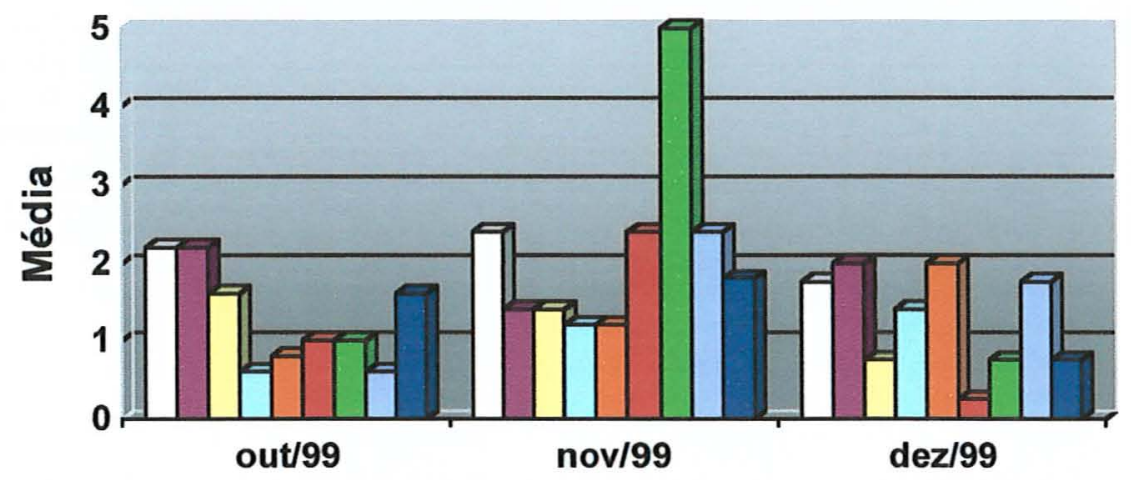

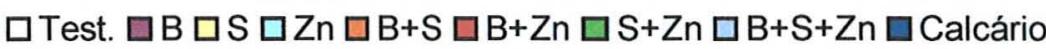

Figura 7 - Notas referente a porcentagem nas folhas em diferentes épocas dos sintomas da MAC, Araguari-MG, 1999. 


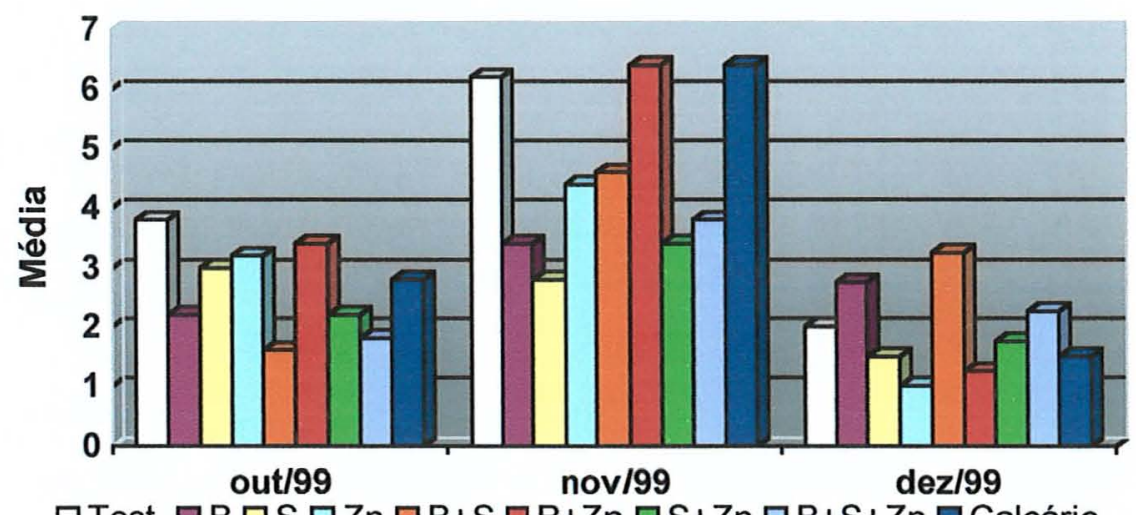

Figura 8 - Número médio de folhas com ácaro B. phoenicis, Araguari- MG, 1999.

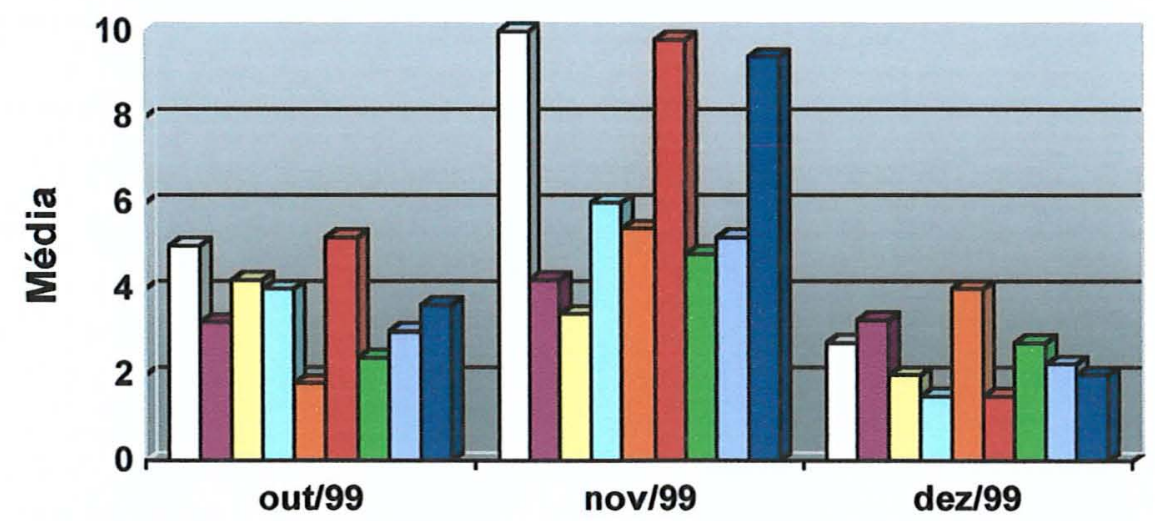

पTest. $\square \mathrm{B} \square \mathrm{S} \square \mathrm{Zn} \square \mathrm{B}+\mathrm{S} \square \mathrm{B}+\mathrm{Zn} \square \mathrm{S}+\mathrm{Zn} \square \mathrm{B}+\mathrm{S}+\mathrm{Zn} \square$ Calcário

Figura 9 - Número médio de ácaros B. phoenicis por parcela, Araguari-MG, 1999.

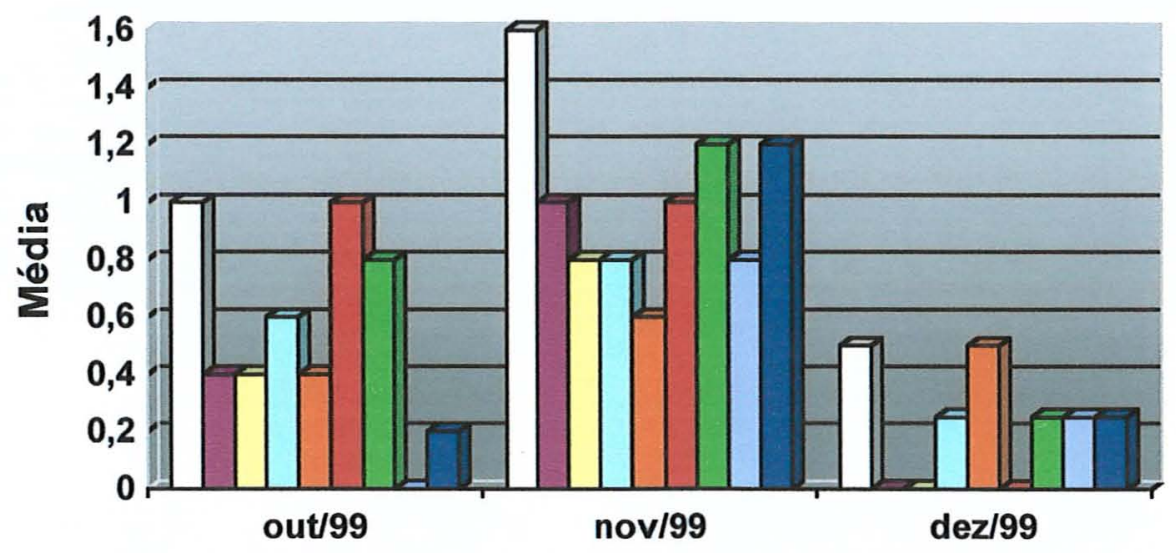

पTest. $\square \mathrm{B} \square \mathrm{S} \square \mathrm{Zn} \square \mathrm{B}+\mathrm{S} \square \mathrm{B}+\mathrm{Zn} \square \mathrm{S}+\mathrm{Zn} \square \mathrm{B}+\mathrm{S}+\mathrm{Zn} \square$ Calcário

Figura 10 - Número médio de ovos de B. phoenicis por parcela, Araguari-MG, 1999. 


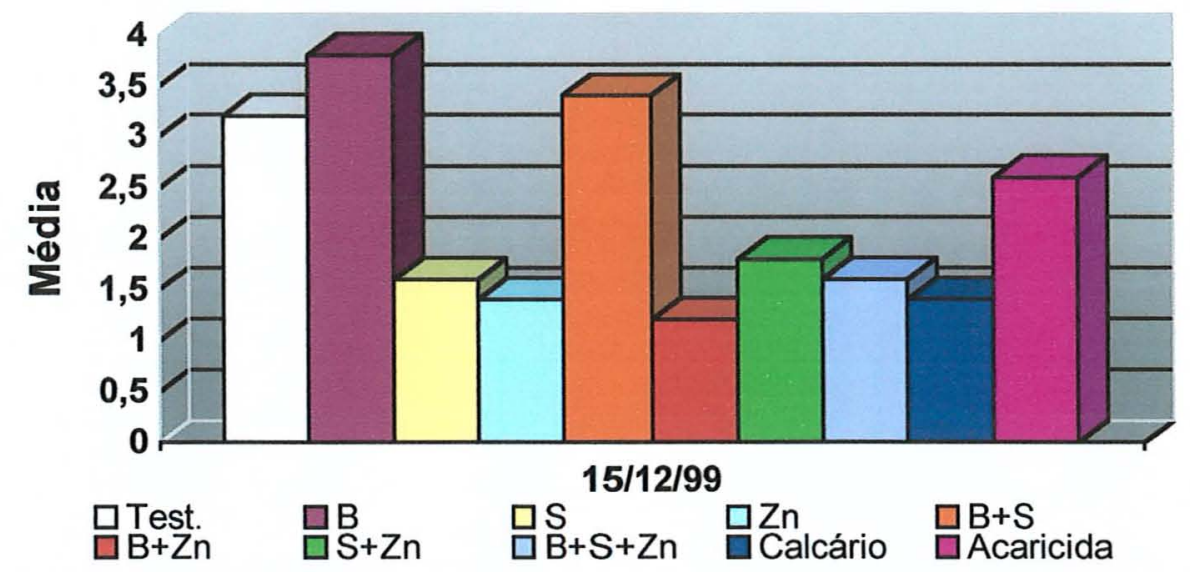

Figura 11 - Número médio de folhas com sintomas da MAC, Araguari-MG, 1999.

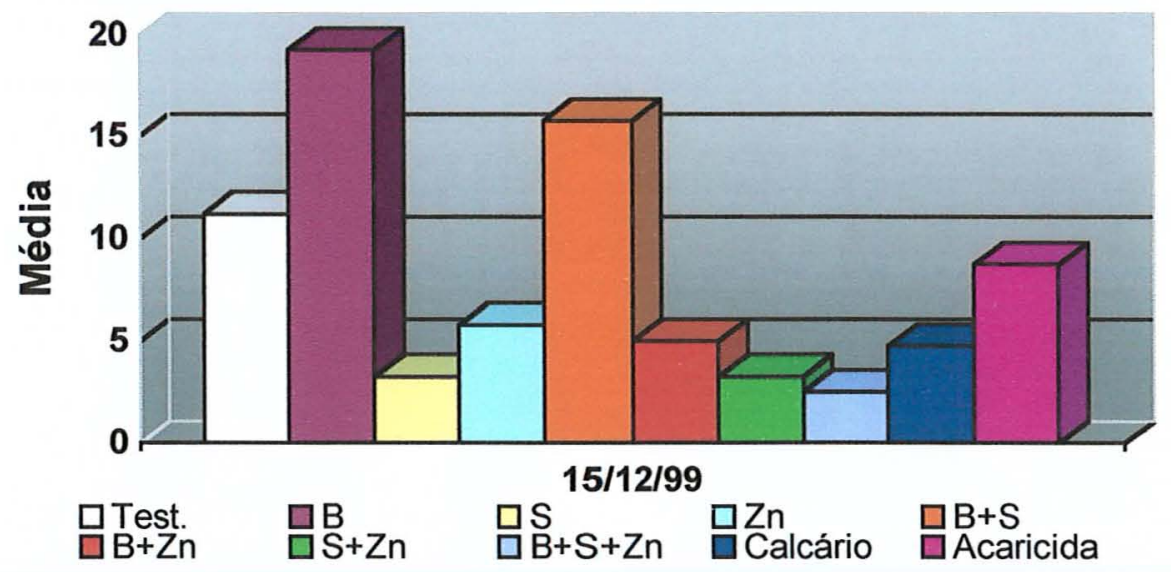

Figura 12 - Número de lesões da MAC por parcela, Araguari-MG, 1999.

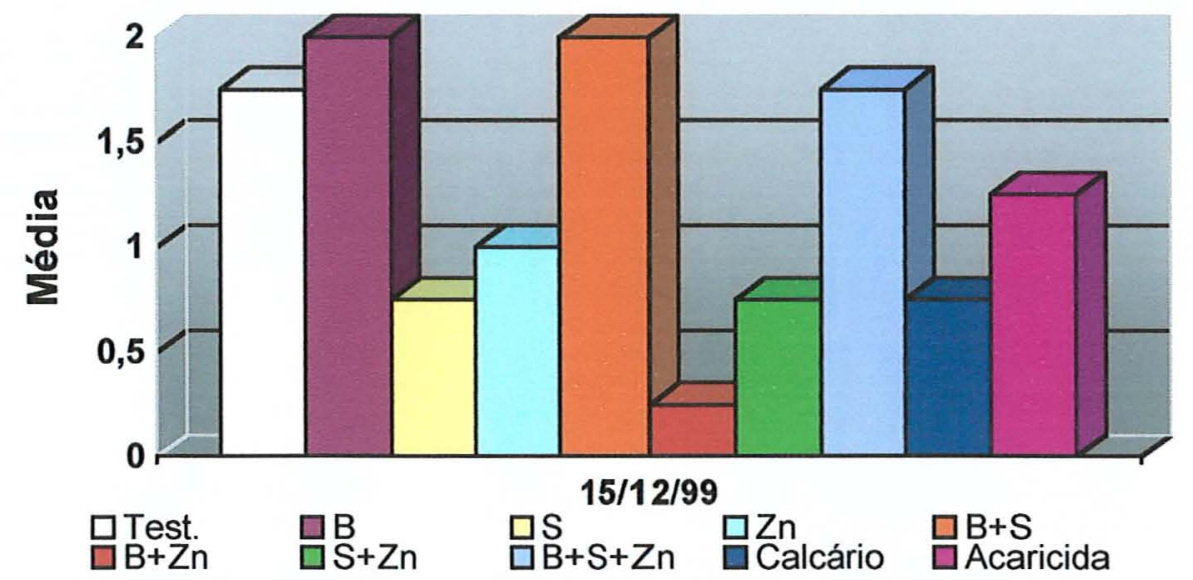

Figura 13 - Notas referente a porcentagem de ataque dos sintomas da MAC Araguari-MG, 1999. 


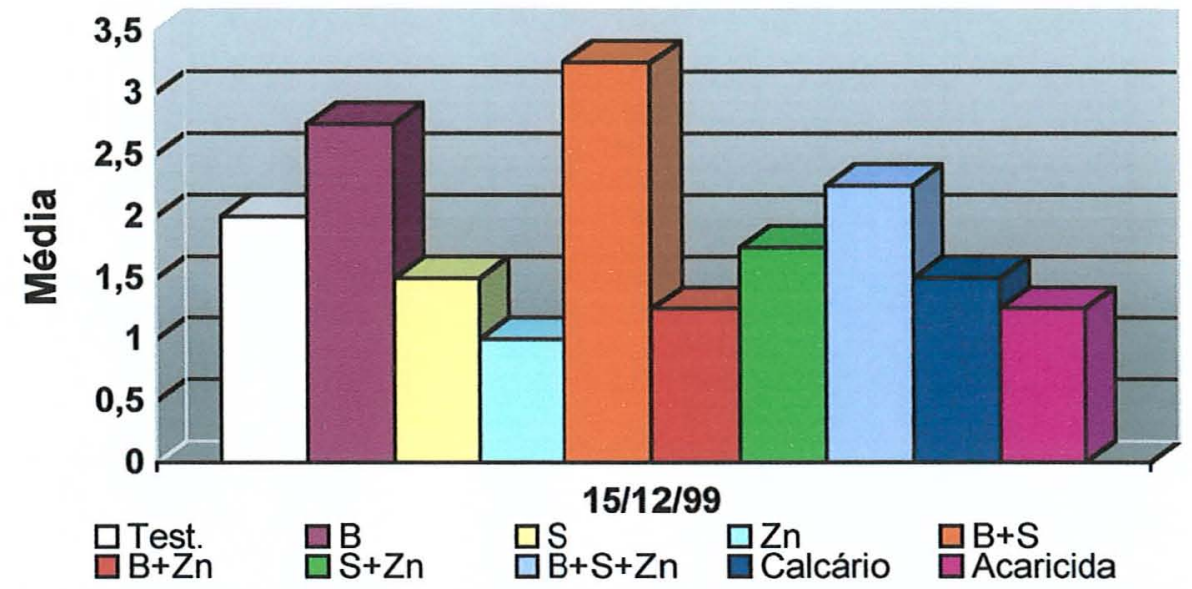

Figura 14 - Número médio de folhas com ácaro B. phoenicis Araguari-MG, 1999.

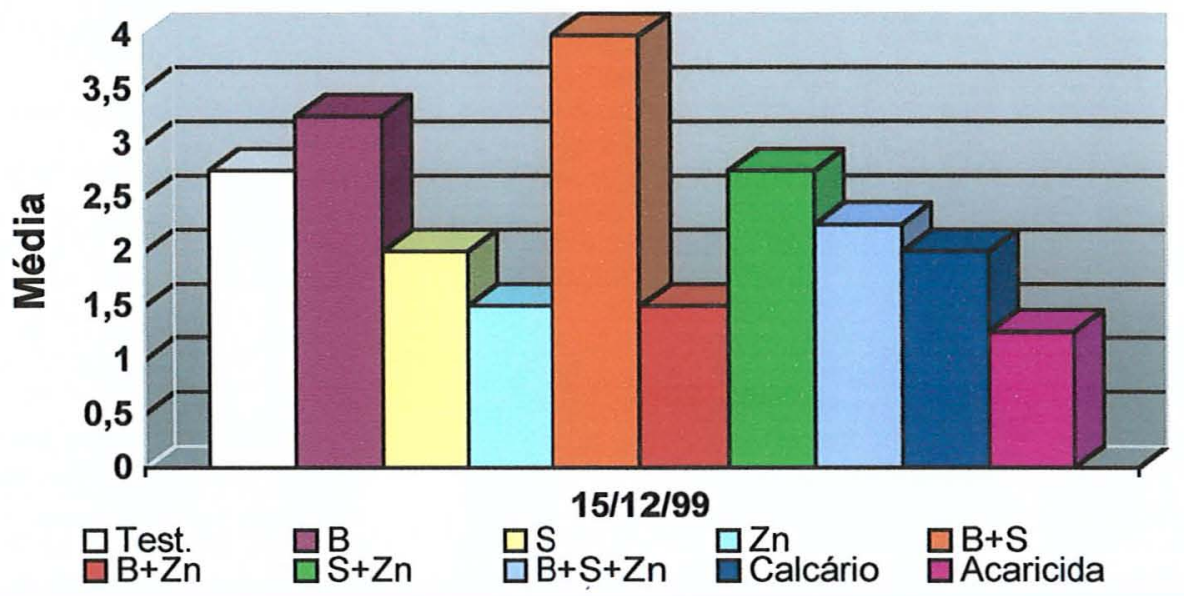

Figura 15 - Número médio de ácaros $B$. phoenicis por parcela Araguari-MG, 1999.

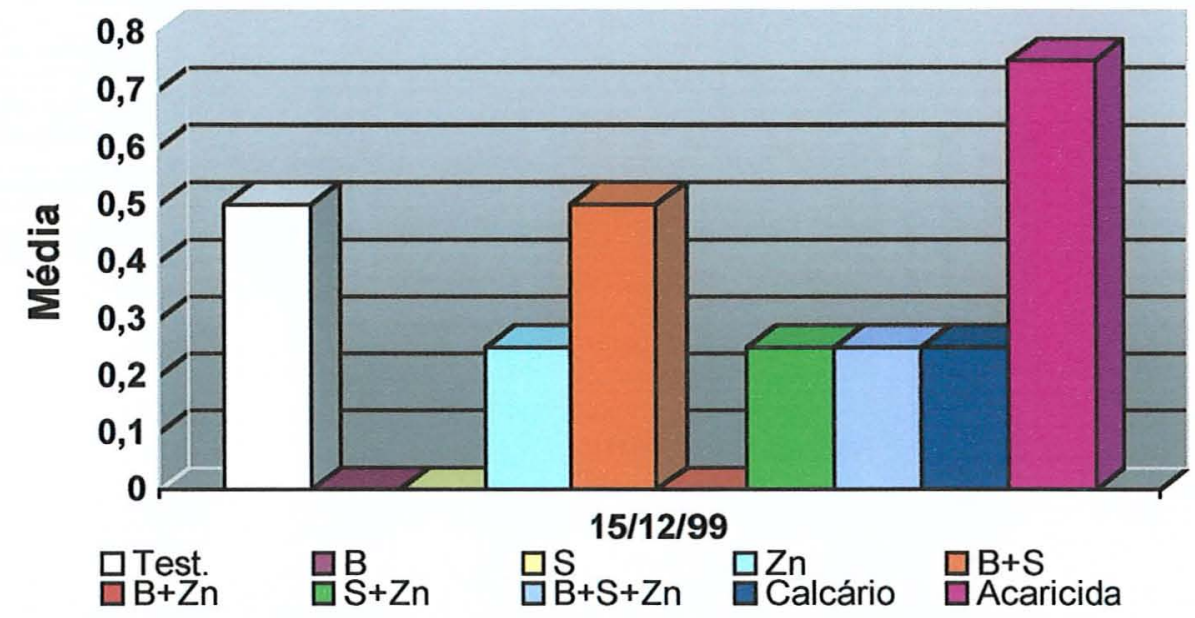

Figura 16 - Número médio de ovos de B. phoenicis por parcela Araguari-MG, 1999. 


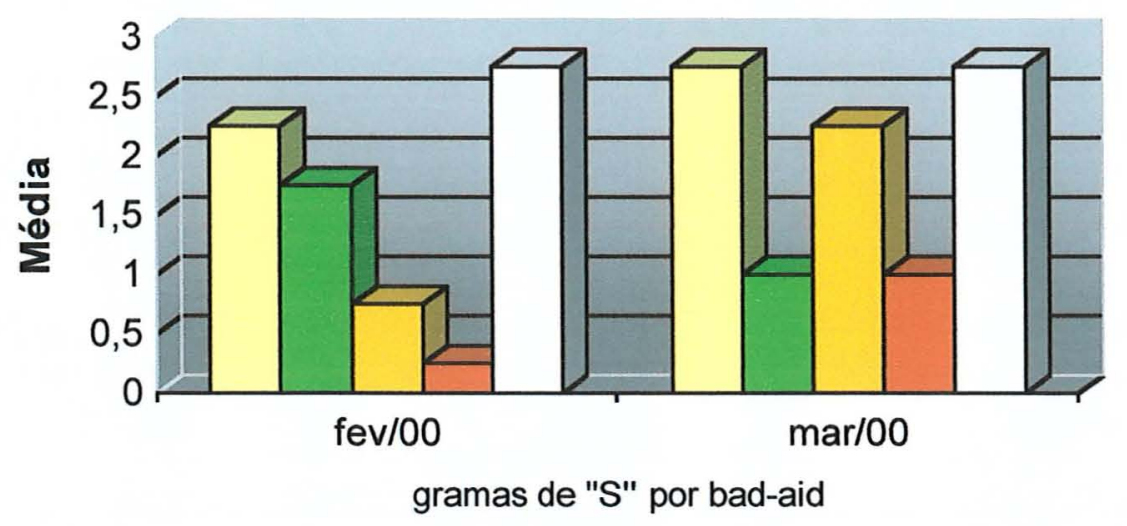

$\square 0,25 \mathrm{~g} \quad \square 0,5 \mathrm{~g} \quad \square 1,0 \mathrm{~g} \quad \square 2,0 \mathrm{~g} \quad \square$ Test.

Figura 17- Número de folhas com sintomas da MAC em cinco folhas por ramo amostradas ao acaso, Araguari - MG

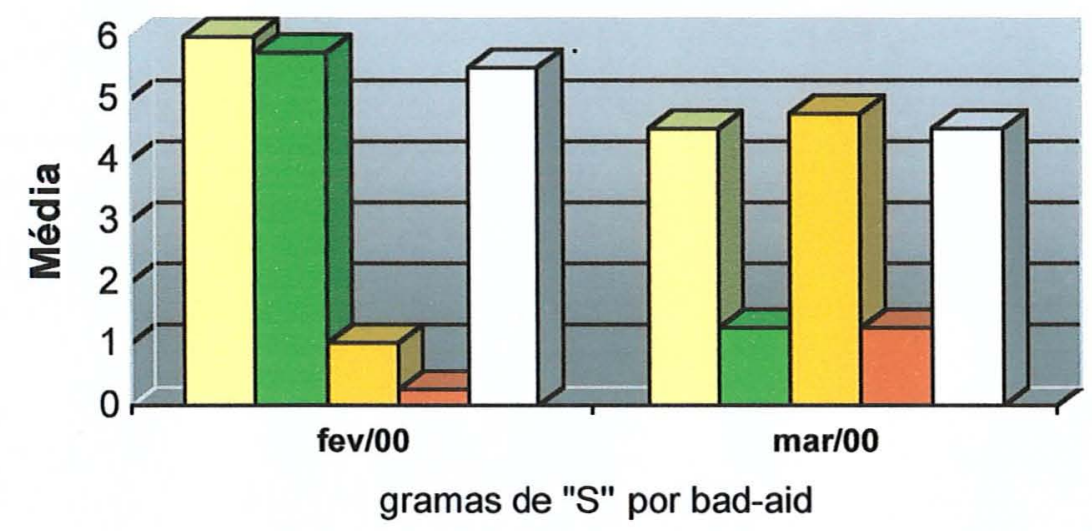

$\square 0,25 \mathrm{~g} \quad \square 0,5 \mathrm{~g} \quad \square 1,0 \mathrm{~g} \quad \square 2,0 \mathrm{~g} \quad \square$ Test.

Figura 18 - Número de manchas por parcela da MAC em cinco folhas por ramo amostradas ao acaso, Araguari - MG

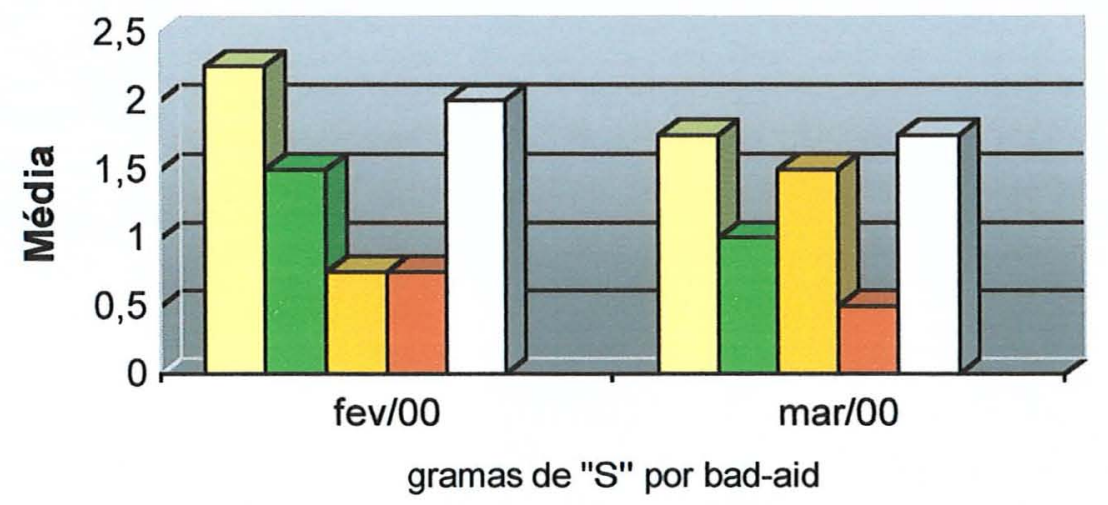

$\square 0,25 \mathrm{~g} \quad \square 0,5 \mathrm{~g} \quad \square 1,0 \mathrm{~g} \quad \square 2,0 \mathrm{~g} \quad \square$ Test.

Figura 19 -.Número de ácaros em cinco folhas por ramo amostradas ao acaso, Araguari - MG 


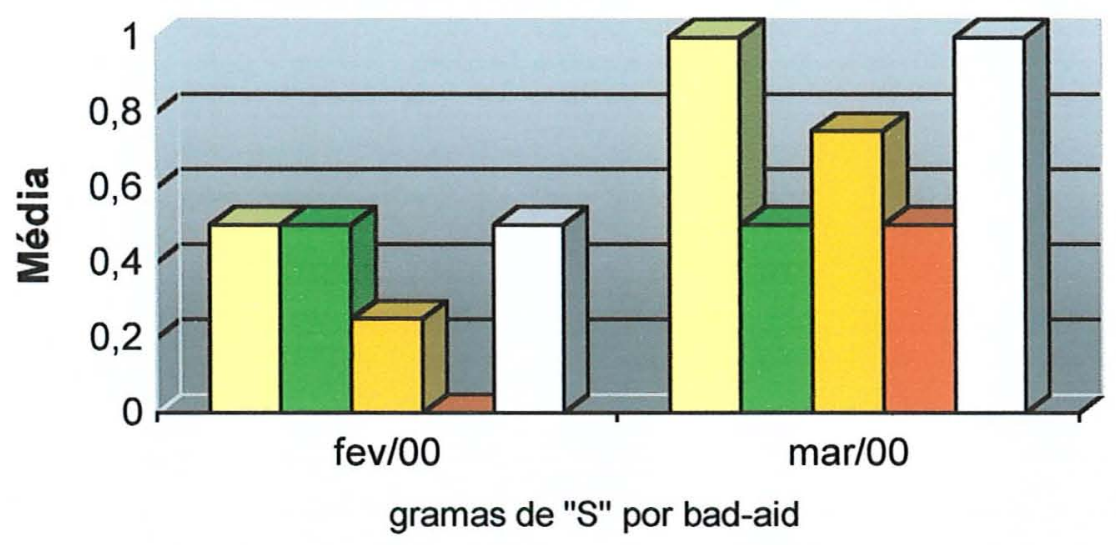
$\square 0,25$
$\square 0,5 \mathrm{~g}$
$\square 1,0 \mathrm{~g}$
$\square 2,0 \mathrm{~g}$
$\square$ Test.

Figura 20 - Número de folhas com sintoma da MAC em cinco folhas por ramo amostradas ao acaso, Espírito Santo do Pinhal - SP.

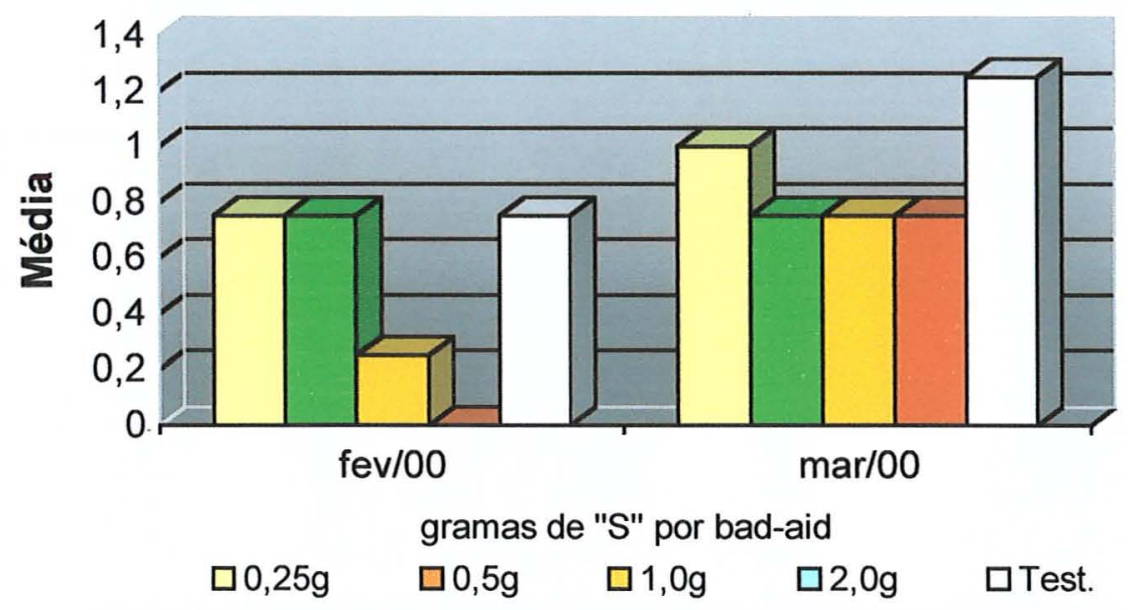

Figura 21 - Número de manchas por parcela da MAC em cinco folhas por ramo amostradas ao acaso, Espírito Santo do Pinhal - SP.

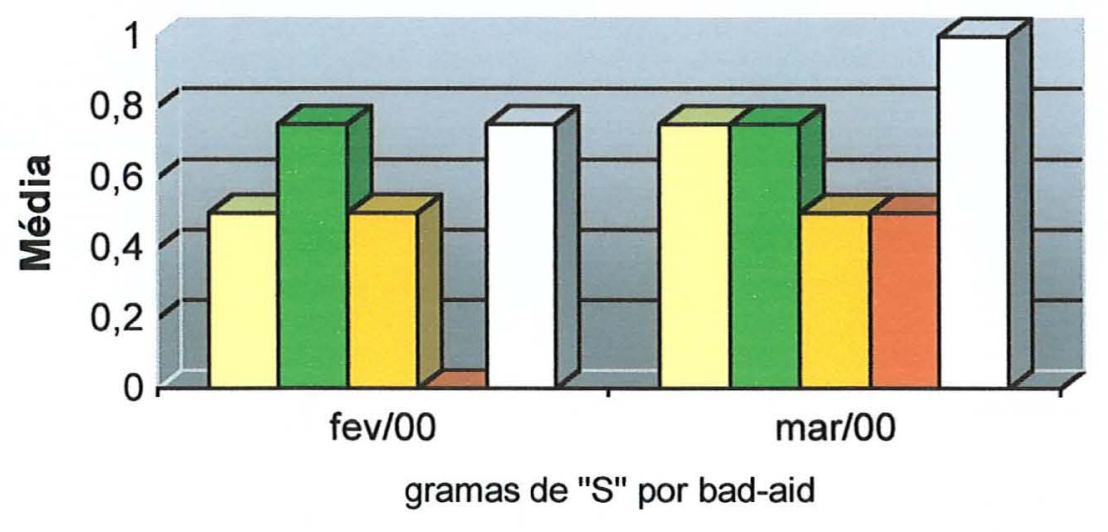

$\square 0,25 \mathrm{~g} \quad \square 0,5 \mathrm{~g} \quad \square 1,0 \mathrm{~g} \quad \square 2,0 \mathrm{~g} \quad \square$ Test.

Figura 22 - Número de ácaros em cinco folhas por ramo amostradas ao acaso, Espírito Santo do Pinhal - SP 


\section{REFERÊNCIAS BIBLIOGRÁFICAS}

ABBOTT, W.S. A metod of computing the effectiveness of an insecticide.

Journal of Economic Entomology, v.18, p.265-267, 1925.

ANDRADE, R.C. de; NAKANO, O. Influência de teores de enxofre sobre a ocorrência do ácaro plano Brevipalpus phoenicis e os sintomas da virose "Mancha Anular" em cafeeiro Coffea arabica L. Ecossistema, v. 23, p.105, 1998.

ANDRADE, R.C. de; FLORCOVSKI, J.L.;GROES .M.V.; CALAFIORI,M.H. Efeito da aplicação de enxofre no solo para controle de ácaro rajado Tetranychus urticae (Koch, 1836) em feijoeiro, Phaseolus vulgaris L. Ecossistema, v.22, p. 21-23, 1997a.

ANDRADE, R.C. de; DEVÓLIO, G.; FLORCOVSKI, J.L.; CALAFIORI,M.H.; SERTÓRIO, R.A. Diferentes manejos da cultura do café (Coffea arabica L.) influenciando a população do ácaro Brevipalpus phoenicis (GEIJSKES,1939). In: CONGRESSO BRASILEIRO DE PESQUISAS CAFEEIRAS, 23., Manhuaçú, 1997. Resumos. Rio de Janeiro: MAA, PROCAFÉ, PNFC, 1997b. p 138-139.

BANZATTO, D.A.; KRONKA, S.N. Experimentação agrícola. Jaboticabal: FUNEP, 1989. 247p. 
BITANCOUT, A. A. A mancha anular, uma nova doença do cafeeiro. O Biológico, v.4, p. 404--405, 1938.

BOS, L. Introduction to plant virology. London: Longman, 1983. 160p.

CARVALHO, C. M.; FIGUEIRA, A. R. Situação atual do vírus da mancha anular em Minas Gerais. In: CONGRESSO BRASILEIRO DE PESQUISAS CAFEEIRAS, 24., Poços de Caldas, 1998. Resumos. Rio de Janeiro: MAA, PROCAFÉ, PNFC, 1998. p 250-251.

CHABOUSSOU, F. Plantas doentes pelo uso de agrotóxicos: a teoria da trofobiose . São Paulo : L\&PM, 1987. 253p

CHAGAS, C.M. Associação do ácaro Brevipalpus phoenicis (Geijskes) à mancha anular do cafeeiro. O Biológico, v. 39, p. 229-232, 1973.

CHAGAS, C.M. Mancha anular do cafeeiro: transmissibilidade, identificação do vetor e aspectos anátomo-patológicos da espécie Coffea arabica L. afetada pela moléstia. São Paulo, 1978. 132p. Tese (Doutorado) - Instituto de Biociências, Universidade de São Paulo.

CHAGAS, C.M.; ROSSETTI, V.; CHIAVEGATO, L.G. Effectiveness of the different life cycle stages of Brevipalpus phoenicis GEIJSKES in leprosis transmission. In: CONFERENCE OF THE INTERNATIONAL ORGANIZATION OF CITRUS VIROLOGISTS, 9., Riverside, 1983. Proceedings. p.211-214. 
CHIAVEGATO, L.G. O ácaro Brevipalpus phoenicis (Geijiskes, 1939) (Acari: Tenuipalpidae) responsavél pela leprose dos citros. In: SIMPÓSIO DE CITRICULTURA, 2., Bebedouro, 1985. Anais. Jaboticabal: FUNEP, 1985. p.35-43.

D'ANTONIO, A .M.; PAULA, V. de; PAULINI, A .E.; GUIMARÃES, P.M. Efeito de piretróides usados no controle do bicho mineiro, Perileucoptera coffeela (Guérin, Ménevelle, 1842), sobre os niveis populacionais do ácaro vermelho 'Oligonychus ilicis (M.c.Gregor, 1919) In: CONGRESSO BRASILEIRO DE PESQUISAS CAFEEIRAS, 8., Campos do Jordão, 1980. Anais. Rio de Janeiro: MAA, PROCAFÉ, PNFC, 1980. p 181-183.

A INFESTAÇÃO de ácaros em cafezais. O Biológico, v. 17, n. 7, p 130, 1951.

KITAJIMA , E. W.; COSTA, A. S. Partículas baciliformes associadas à mancha anular do cafeeiro. Ciência e Cultura, v. 24,p. 542-545, 1972.

KITAJIMA , E. W.; REZENDE, J. A. M.; CHIAVEGATO, L.G.; PIZA JR., C de T.; MOROZINI, W. Associação de partículas semelhantes às do virus da leprose-dos-citros com sntomas de necrose na haste e manchas em frutos do maracujazeiro. Fitopatologia Brasileira, v.21, p. 425, 1996. Suplemento

MAIA, I.G.; BUSOLI, A . C. Efeito de doses e fontes de nitrogênio sobre a fecundidade de Tetranychus urticae $(\mathrm{KOCH}, 1836)$ em algodoeiro $\mathrm{CV}$. IAC 20 (Gossypium hiirsutum L.) Anais da Sociedade Entomológica do Brasil, v. 21, n. 3, p. 347-356, 1992. 
MATIELLO, J.B.; PAULINI, A.E.; LESSI, R. Ocorrência do ácaro plano, Brevipalpus phoenicis e Leprose em cafeeiros conillon, no Espírito Santo. In: CONGRESSO BRASILEIRO DE PESQUISAS CAFEEIRAS, Águas de Lindóia, 22., 1996. Resumos. Rio de Janeiro: MAA, PROCAFÉ, PNFC, 1996. p.14.

MELLORS , W.K.; PROPTS, S.E. Effects of fertilizer level, fertility balance, and soil moisture on the interaction of two- spotted spider mites (Acarina : Tetranichidae ) with radish plants. Environmental Entomology, v.12, p. $1239-1244,1983$.

MENGEL, K.; KIRKBY, E.A. Principles of plant nutrition. 4.ed. Bern: International Potash Institute, 1987. 687p.

MUSUMECI, M.R.; ROSSETTI, V. Transmissão dos sintomas da Leprose dos citros pelo ácaro Brevipalpus phoenicis. Ciencia e Cultura, v.15, p. 228, 1963.

OLIVEIRA, C. A. L. de. Flutuação populacional e medidas de controle do ácaro da leprose Brevipalpus phoenicis (GEIJSKES, 1939) em citrus. Laranja, v.1, n.7, p.1-32, 1986.

OLIVEIRA, C. A. L.; REIFF, E. T. Eficiência de vários produtos químicos no controle do ácaro transmissor da mancha anular, Brevipalpus phoenicis na cultura do cafeeiro. In: CONGRESSO BRASILEIRO DE PESQUISAS CAFEEIRAS, 24., Poços de Caldas, 1998. Resumos. Rio de Janeiro: MARA, 1998a. p 140. 
OLIVEIRA, C. A. L.; REIFF, E. T. Influência do volume de calda aplicada de acaricidas no controle do Brevipalpus phoenicis transmissor da Mancha Anular do Cafeeiro. In: CONGRESSO BRASILEIRO DE PESQUISAS CAFEEIRAS, 24., Poços de Caldas, 1998. Resumos. Rio de Janeiro: MAA, PROCAFÉ, PNFC, 1998b. p 140

PAPA, G.; Ocorrência, sintomas e controle do ácaro da leprose, Brevipalpus phonicis (GEIJSKEN, 1939) (Acari : Tenuipaupidae), na cultura do café. In: CONGRESSO BRASILEIRO DE PESQUISAS CAFEEIRAS, 23., Manhuaçú, 1997. Resumos. Rio de Janeiro: MAA, PROCAFÉ, PNFC, 1997. p 231233.

PAULINI , A .E.; MIGUEL, A .E. MANSK,Z., Efeito de fungicidas sobre o aumento da população do ácaro vermelho Oligonichus ilicis (M.C. Gregor 1919) em cafeeiros. In: CONGRESSO BRASILEIRO DE PESQUISAS CAFEEIRAS, 3., Curitiba, 1975. Rio de Janeiro; MAA, PROCAFÉ, PNFC , 1975. p.38-40.

PAZZINI, A.R.; PARRA, J.R.P. Ecologia nutricional de insetos e suas implicações no manejo de pragas. São Paulo: Manole, 1991. 359 p.

REIS, P.R.; SOUZA, E.O.; TEODORO, A .V.; Distribuição do ácaro Brevipalpus phonicis (GEIJSKEN, 1939) ( Acari : Tenuipaupidae), em cafeeiro. In: CONGRESSO BRASILEIRO DE PESQUISAS CAFEEIRAS, 23., Manhuaçú, 1997. Resumos. Rio de Janeiro: MAA, PROCAFÉ, PNFC, 1997. p 181-183. 
RODRIGUES, J.C.V. Leprose dos citros cito-histopatologia, transmissibilidadde e relação com o vetor Brevipalpus phoenicis GEIJSKES (ACARI: TENUIPALPIDAE). Piracicaba, 1995. 79p. Dissertação (Mestrado) - Centro de Energia Nuclear na Agricultura, Universidade de São Paulo.

SILBERSCHMIDT, K. A transmissão experimental da mancha anular do cafeeiro. O Biológico, v.7, p. 93-99,1941.

SUDOI, V.; KHAEMBA, B. M.; WANJALA, F.M. Influence of soil applied nitrogen ( NPKS 25: 5:5:5) on Brevipalpus phoenicis Geijskes ( Acari : Tenuipalpidae ) mite incidence and damage symptoms on tea. Annals of Applied Biology, v. 128, p. 13-19, 1996. 